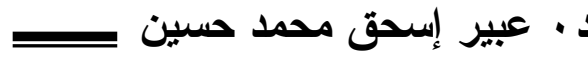

البناء التقابلي وإنتاج المعنى في المدائح النبوية

عند أحمد شوقي

(")

د. • عبيز إسحق محمد حسين

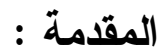

يسعى هذا البحث إلى تبيان أن نص المديح النبوي عند أحمد شوقي يقوم

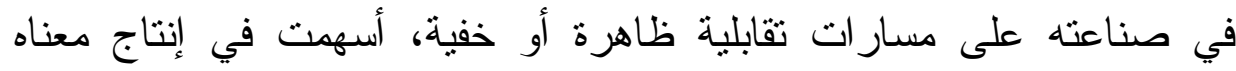
و إيصاله إلى المتلقي؛ حيث نرى الباحثة أن بنية التقابل من الأنساق العميقة

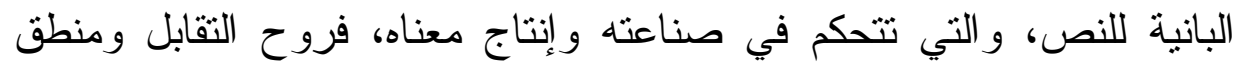

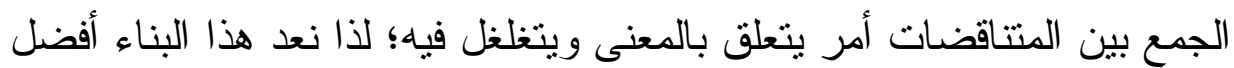

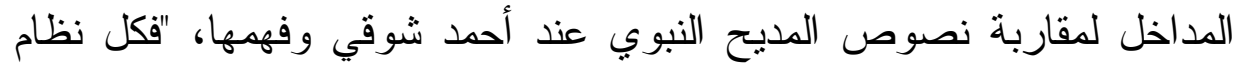
من المعنى يتطلب نظاماً من شكل القول، وهو ما يسمح بنتبع نطور أثنكال التعبير عن المعاني في الأدب وتطور الخطاطات الذهنية المتحكمة فيه"(') و إذا كان لكل نص تقابلاته و آلياته الخاصة الني يستتد إليها في صناعته؛ لذا تهدف هذه المقاربة إلى رصد هذه الآليات، وبيان مدى إسهامها في تثكيل المعنى، و إبراز دور ها في تحقيق جمالية النص وفنيته، إضافة إلى بيان دورها

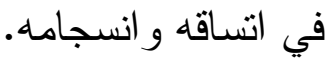

أستاذ مساعد بكلية التربية (أدب حديث ونقد) الخرج - جامعة الأمير سطام بن عبد العزيز - المملكة العربية السعودية.

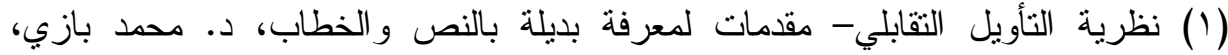

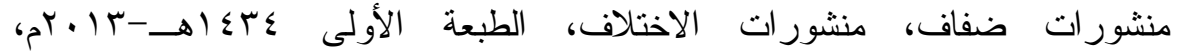

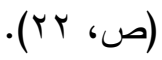




\section{البناء التقابلي}

أما عن منهجية الدراسة فقد تبنى البحث وجهة نظر جديدة مستمدة أصولها

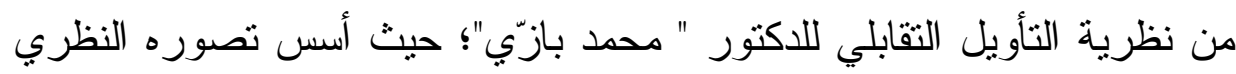

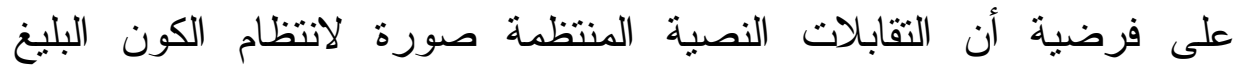
وتتاغمه، وبلاغة بيانه الاعتبارية المتجلية في انتظام المعاني والأفكار انتظاماً

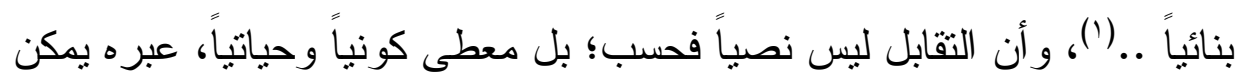

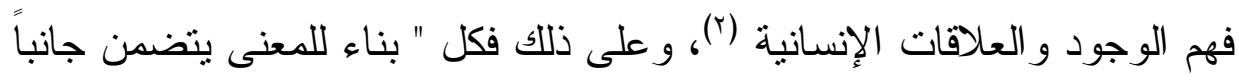

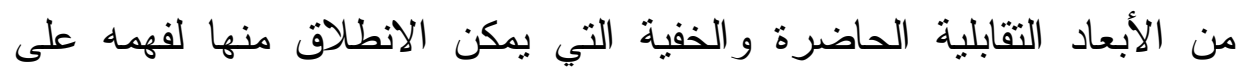

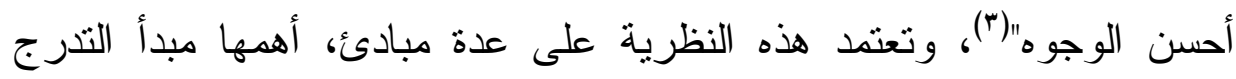

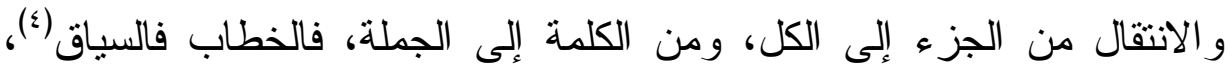

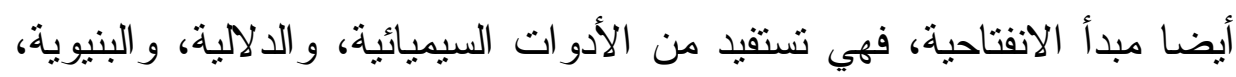

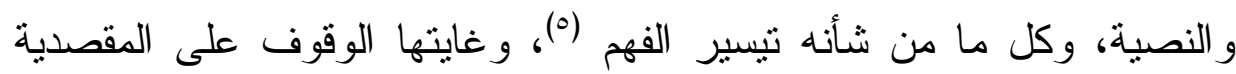

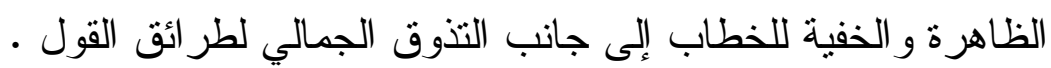

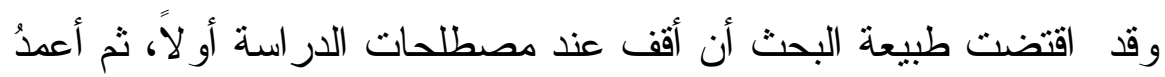

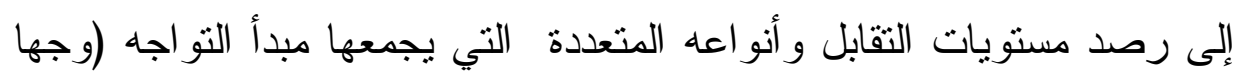
لوجه ) وذلك من خلا ثلاثة محاور رئيسة، فاختص المحور الأول بدراسة

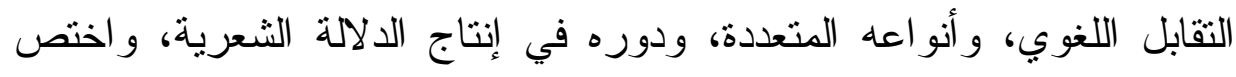

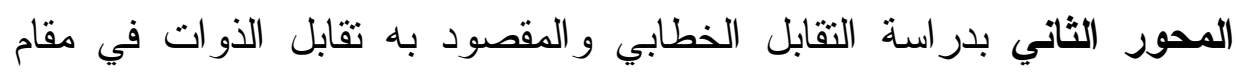

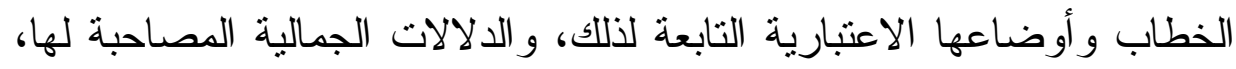

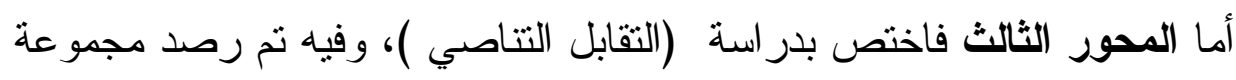

$$
\begin{aligned}
& \text { ( () نظرية التأويل الثقابلى، مقدمات لمعرفة بديلة بالنص و الخطاب ، (ص، ب؟؟). }
\end{aligned}
$$

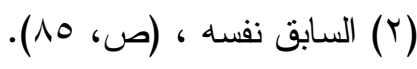

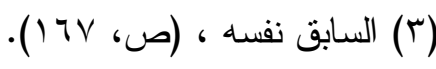

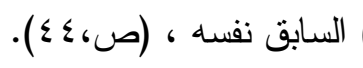

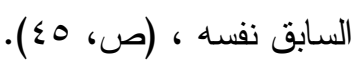


د · عبيز إسحق محمد حسين عـ

من المقابلات النصية التي دخلت في صناعة ونسج نص المديح النبوي بكيفيات مختلفة؛ لإغناء المعنى وإحداث أثز جمالي، وقد اقتضت طبيعة الدر اسة الفصل بين المستويات الثلاثة ؛ لتقديم تصور منكامل لآليات هذا البناء، ثم أنهيت البحث بخاتمة اثتملت على أهم النتائج التي ثم التوصل إليها . وقبل أن أنتقلَ إلى الجانب التطبيقي يجدرٌ بي أن أنوقف عند مصطلحات

\section{أولاً: مصطلحات الار اسة:}

المقصود بالبناء التقابلي: مفهوم التقابل في اللغة بوجه عام هو المواجهة،

فكل شيء يواجه شيئا آخر فهو يقابله ويعارضه، يقول ابن منظور (ت1 و المفهوم الذي يعتمده البحث هو " إنه تواجه شيئين، أو شخصين، أو وضعين أو حالين قد يدل أحدها على الآخر بحضوره وإن كان غائباً، فهو علامة وسيماء على بنية تقابلية قائمة على الحضور التام أو الجزئي، وسواء

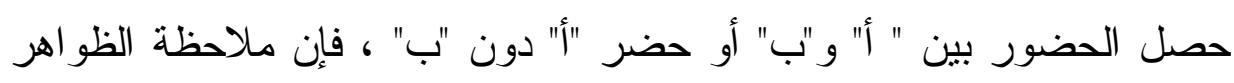
من حولنا عبر التمعن فيها و إدر اكها يقتضي حضور زوجها إما حضوراً مادياً أو معنوياً "(ץ)، وبذلك تكون مظاهر التقابل كثيرة ومتتوعة يجمعها مبدأ التو اجه " وجهاً لوجه"، فهو لا يقف عند حدود البلاغة العربية الكلاسيكية؛ بل يتسع ليثمل التقابلات اللغوية و الخطابية و السياقية، ومستلزمات السياق الخارجي، كما أنه يتخذ صور اً وتشكلات شتى متحكمة في صناعة المعنى وتأويله .

$$
\text { (1) لسان العرب، ابن منظور -مادة ( ق-ب-ل ) ) }
$$

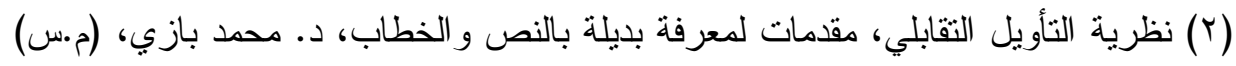

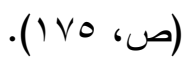


ونفهم من ذللك أن التقابل هو الروح البانية للمعاني، وأنه ليس تام الحضور

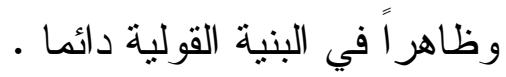

أما المدائح النبوية فهي غرض فئة دائها . فئري قديم ينصب على مدح الرسول

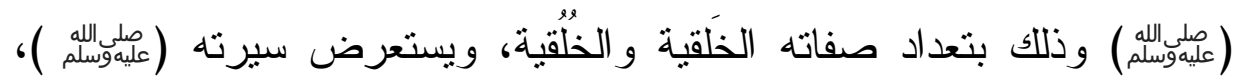

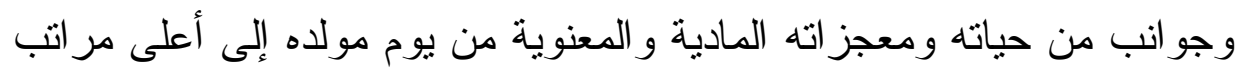

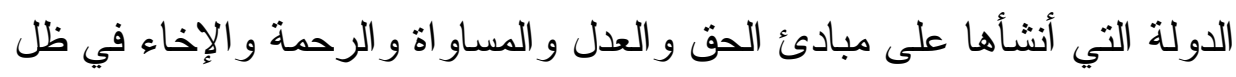

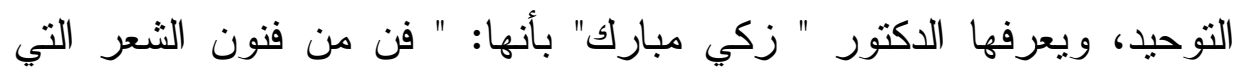

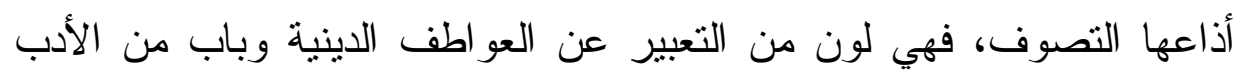

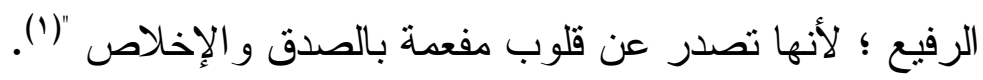

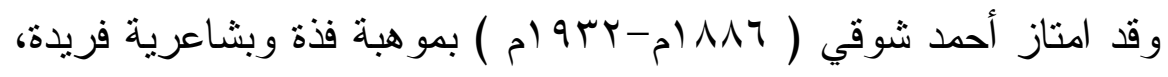
فنظم قصائد في المديح النبوي تفيض بالحب الصنادق و والعاطفة الجيانشة؛ حيث

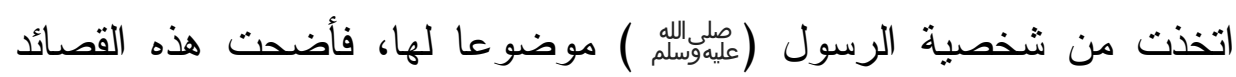

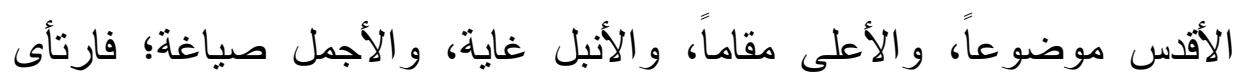

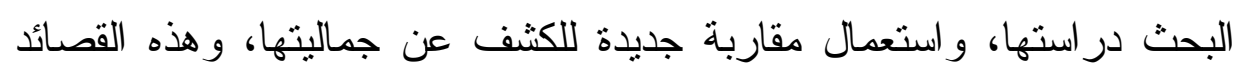

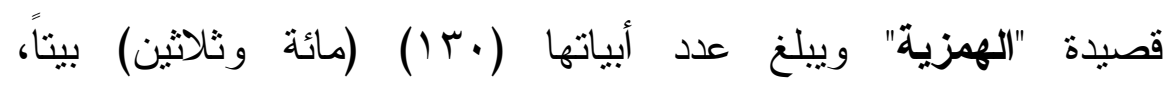
ومطلاعُها:(؟)

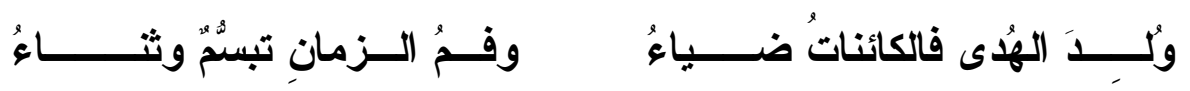

(1) الددائح النبوية في الأدب العربي، د. زكي مبارك، منشور ات المكتبة العصرية، صيدا-

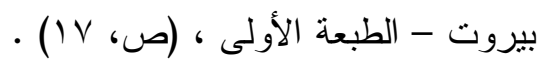

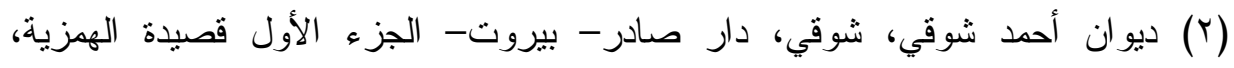

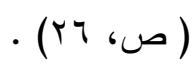




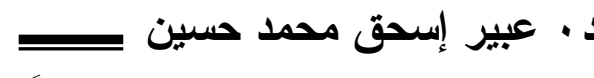

وقصيدة "ذكرى المولد"، وييلغ عدد أبياتها (V)( و احدًا وسبعين ) بيتاً،

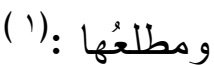

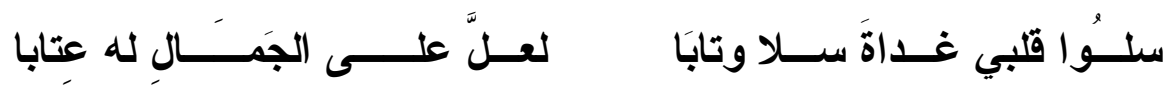
وقصيدة " نهج البردة " وبيلغ عدد أبياتها (.9 (1) مائة وتسعين ) بيتاً،

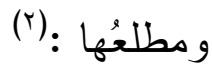

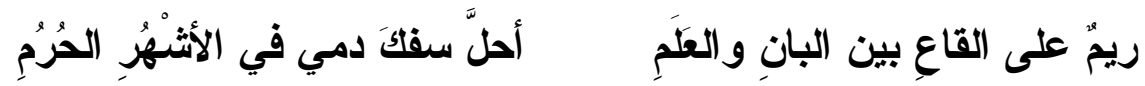
وبذللك يبلغ عدد أبيات تللك الذخائر النبوية الخالدة ( ( اج) ( ثلاث مائة وو احدًا وتسعين) بيتاً، وقد أخرجها أحمد شوقي من باب المديح، وأدخلها في

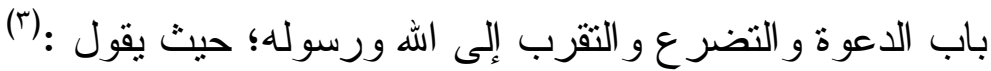

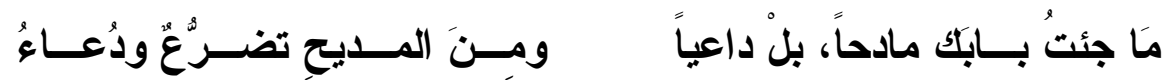
ومن ثم تأتي هذه الدراسة لتتبنى منهجية (د. محمد بازّي )، وتبحث عن مستويات التقابل في تلك الذخائر الخالدة عند أحمد شوفي . ثانياً :مستويات التقابل : المتأمل في القصائد سالفة الذكر يجد أن مظاهر التقابل كثيرة ومنتو عة، وقد تم تقسيمها إلى ثلاثة مستويات رئيسة وهي: (التقابل اللغوي، و التقابل الخطابي، و التقابل التناصي). المحور الأول : التقابل اللغوي، ويمكن تعريفه بأنه "وضع لغوي ينركب

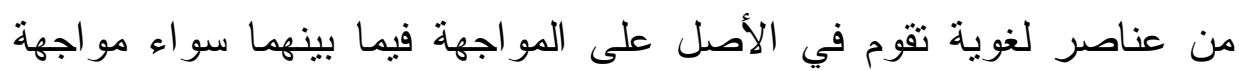
التقابلات أو التخالفات، أو التماثلات، وقد تكون العناصر اللغوية بسيطة كتقابل

$$
\begin{aligned}
& \text { ( ) ديو ان أحمد شوقى ، (ص، مه ). }
\end{aligned}
$$

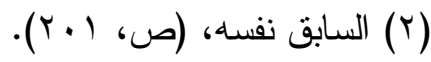

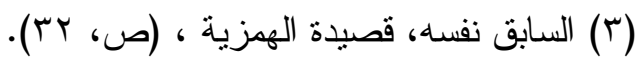

$$
\begin{aligned}
& -0 \leqslant r-
\end{aligned}
$$


الضدين، أو المتخالفين، أو المتماتلين، وقد تكون مركبة كتقابل الجملة بالجملة

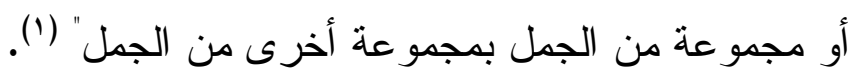

ولهذا النوع حضور واسع في قصائد المديح النبوي، وقد اتخذ أنماطياً

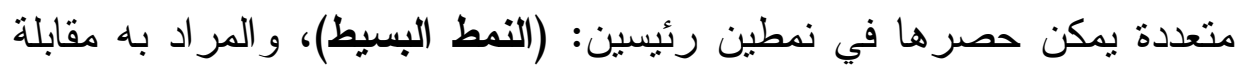

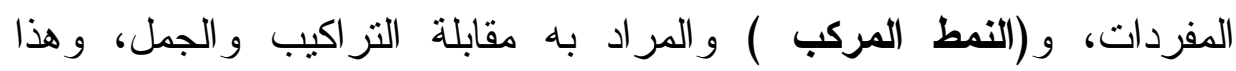

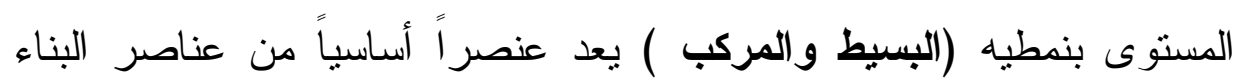
الثعري في قصائد المديح النبوي. فإذا نظرنا إلى النوع الأول من أنو اع النقابل اللغوي وهو التقابل البسيط؛

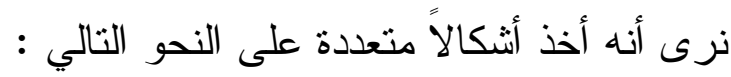

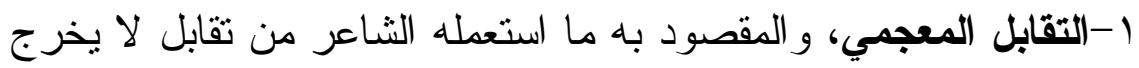
عن أصل الوضع اللغوي؛ "حيث يتم بناء التزاكيب فيه على المجاورة القائمة على التضاد "()، وقد حرص الثناعر في هذا النوع على الانسجام بين الأضداد

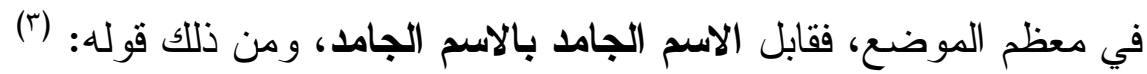

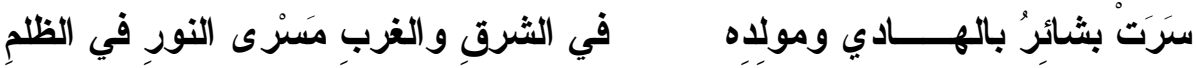
فقد حوى البيت مقابلة مكانية بين (الثرق والغرب)، تعبر عن مساحة و اسعة من الأبعاد و الاتجاهات المكانية المختلفة؛ لييرز الثشاعر من خلالها عموم ولئه

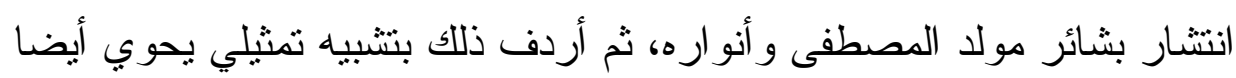

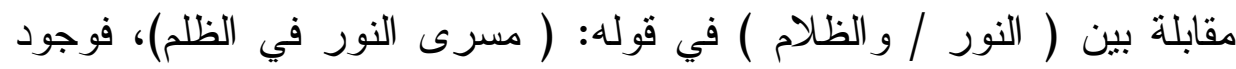

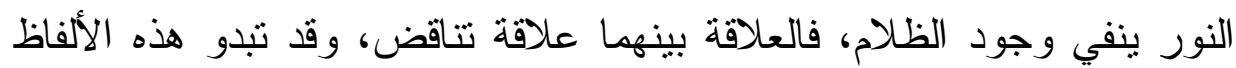

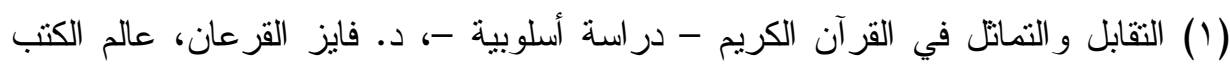

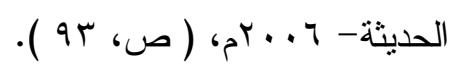

بناء الأسلوب في شعر الحداثة - النكوين البديعي، دان د. محمد عبد المطلب،

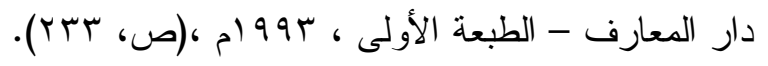

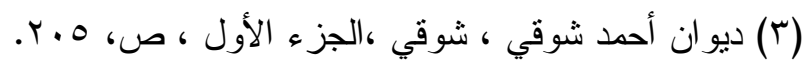




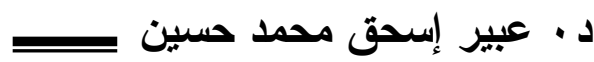

متضادة؛ لكنها في حقيقة الأمر متكاملة جاء بها الثاعر؛ ليرسم صورة مفادها

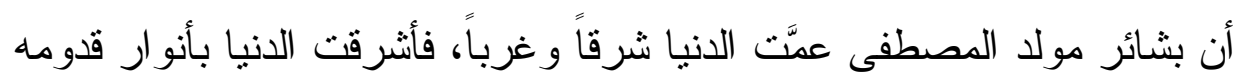
(عليموسلم ) ) و انز احت ظلمات مولم الجهل.

$$
\text { أيضا قوله : ( ) }
$$

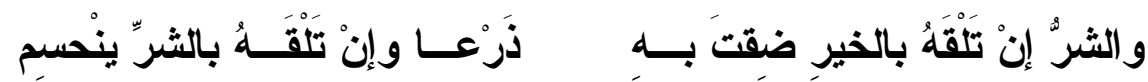
فقد جاء التقابل في سلسلة من ثناثة أطر اف محور ها كلمة (الثر)، فالعلاقة بين الطرف الأول و الثاني( الثر / بالخير ) علاقة تقابل، و علاقة الطرف الأول بالثالث ( الثر / بالثر ) علاقة تماثل، على النحو التالي :

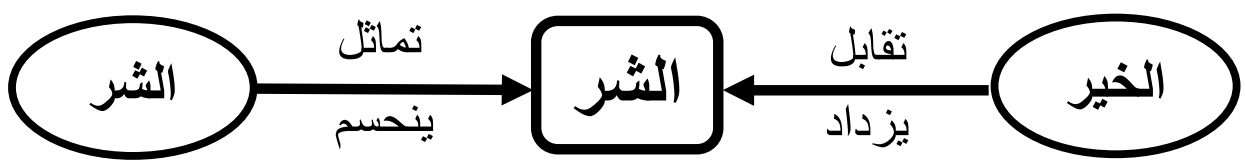

وقد أحكمت الجمل الشرطية هذه السلسلة دن المتقابلات، فالجملتان الشرطيتان: ( إن تلقه ضقت ...إن تلقه ينحسم ) مرتبطتان بكلمة (الثر) في هـ أول الجملة، هذا الثر إذا قوبل بالخير في جملة الثرط الأولى؛ فتكون النتيجة يزداد الشر ويضيق الناس به، و إذا قوبل بالثر ( أي بالجزاء و العقاب على بلى

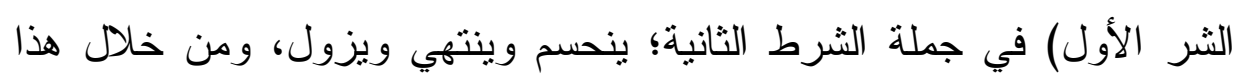

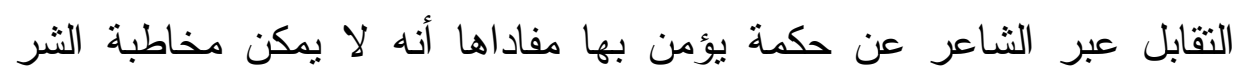
بالخير و الموعظة الحسنة، وأن العقاب يجب أن يكون من جنس العمل. (ץ): كما قابل الاسم الجمع بالاسم الجمع، ومن ذلك قولة

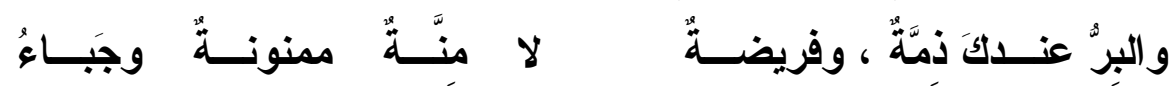

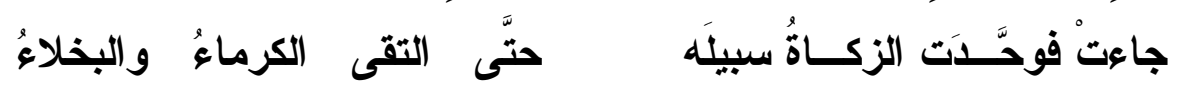

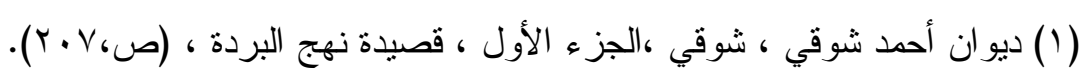

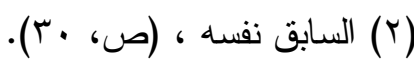


فقد قابل الثاعر الجمع بالجمع ( الكرماء/ و البخلاء )، وقد نو الت اللفظتان؛

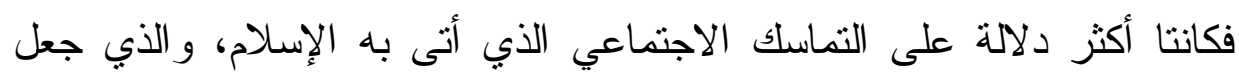

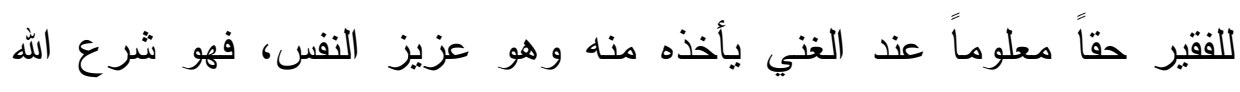

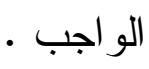

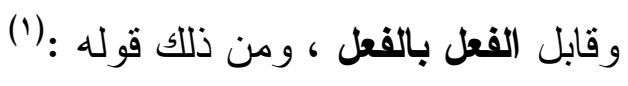

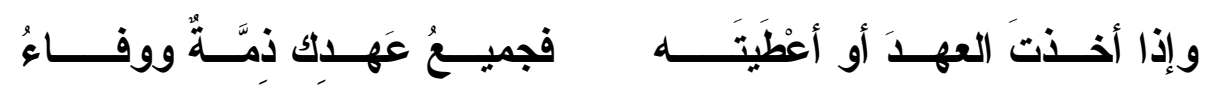

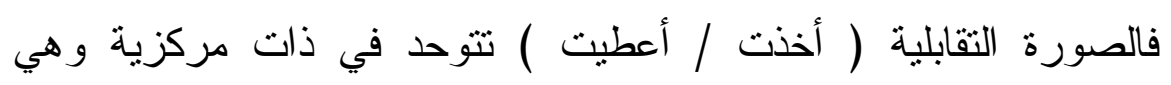

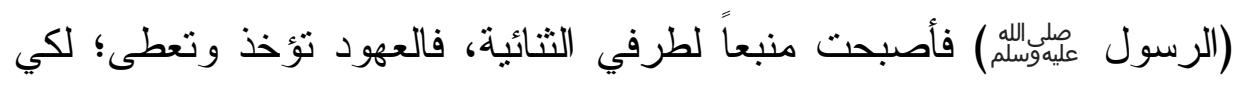

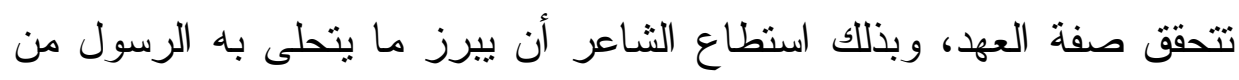

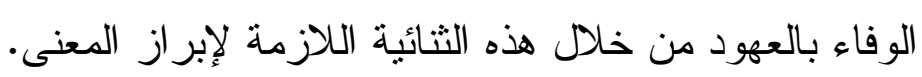

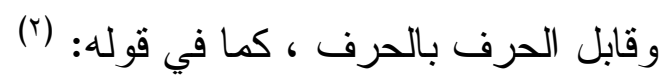

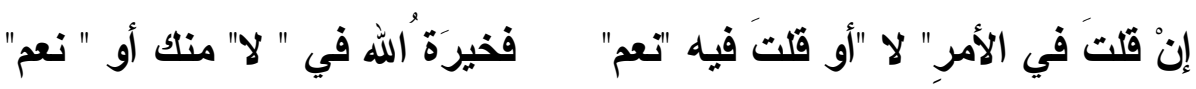
فقد قابل بين حرف الإيجاب " نعم " وحرف النفي " لا "، للإبانة عن حكمة

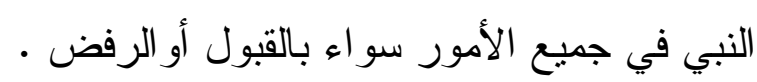

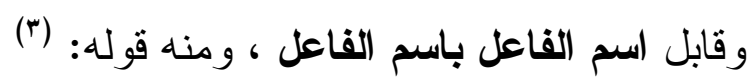

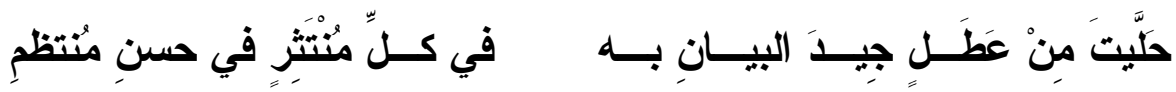
فقد جاء الثقابل على صيغة واحدة هي اسم الفاعل (منتزر / منتظم)؛ ليصف

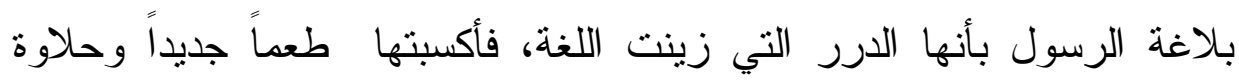

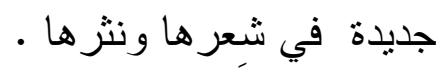

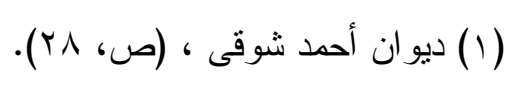

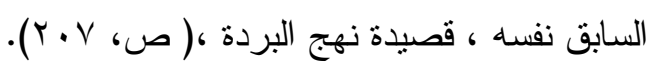

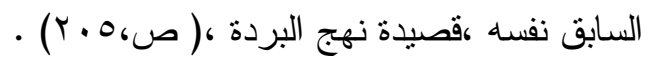




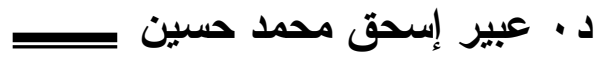

وقابل صبغة المبالغة بصيغة المبالغة ، كقوله: (')

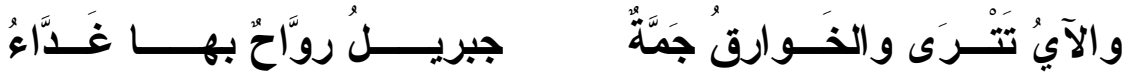

نلاحظ أن التقابل ( روَّاح / غدَّاء ) قد التقى في رابط و احد هو ( جبريل-

عليه السلام )؛ فلفظة (روَّاح) مرتبطة بالملك جبريل، كما أن لفظة (غدَّاء) كذلك، فمهمة جبريل في تبليغ الوحي إلى الرسول الكريم تقتضي هاتين اللفظتين، فهو موقف قائم على الثنائيات المتضادة التي ثتفق مع مهمة هذا الملك، فالتقابل هنا يشير إلى التكامل لا التضاد، وله دوره في تكثيف الصورة

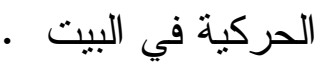

كما قابل صيغة أفعل للتفضيل بصيغة أفعل، ومن ذلك قوله : (r)

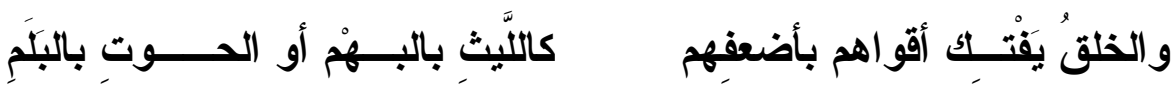

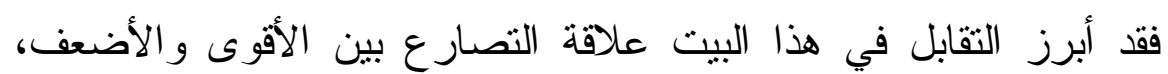
وذلك بقوله: ( أقواهم بأضعفهم )، ثم أكد هذه المقابلة اللغوية بمقابلة سياقية تجري مجرى الاستشهاد على التقابل الأول والحجة على صحته؛ حيث الأسد يفتزس ولا الغنم الصغير الضعيف، و الحوت يلتقم صغار السمك، وهي مقابلات تعتمد على المشاهدة الو اقعية أتى بها الثاعر ؛ لتكون صورة حاضرة يؤكد بها المعنى في ذهن المنلقي - المن يتضح مما سلف أن استخدام الصيخ المثماثلة على هذا النحو أدى إلى خلق نوع من التوازن والانسجام على مستوى البيت الثعري، إضافة إلى إثراء المعنى وتكثيفه .

r- التخالف ، وفيه " يتم بناء التقابل بالاعتماد على التخالف لا التضاد، أي أن نكون اللفظة الأولى مخالفة للثانية على نحو شبيه بالتضاد مع ملاحظة

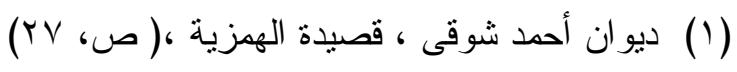

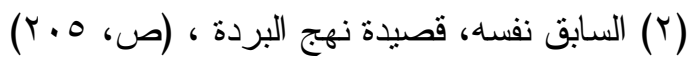


وجود تتاسب بين الطرفين، فهو تخالف من جانب وتتاسب من جانب آخر ،

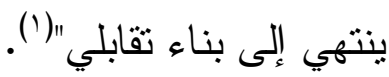

وفي هذا النوع بيتعمل الثشاعر ما ينوب عن الضد المعجمي الأصلي

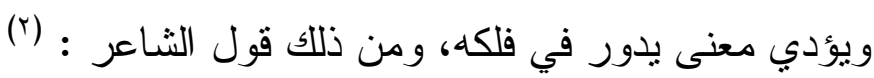

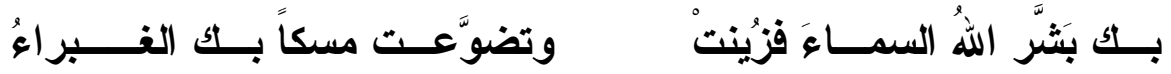

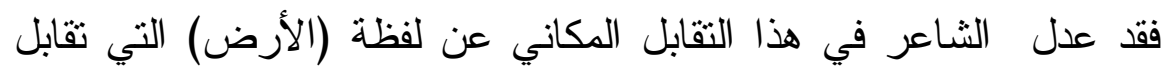

(السماء) و أتى بلفظة (الغبراء)؛ لدو اعي الموسيقى، وأسبخ على ألفاظ التقابل

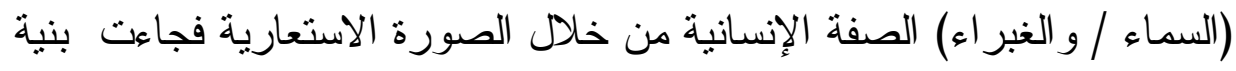
التقابل أكثر جمالاً و إيحاء.

r- التقابل السياقي: وهو ما انقطعت صلته تماما بالوضع اللغوي

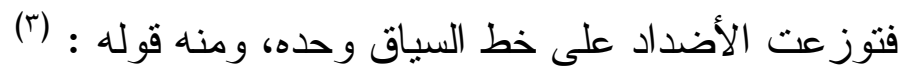

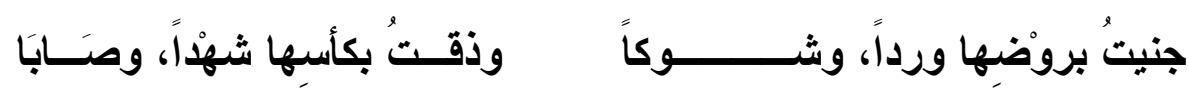

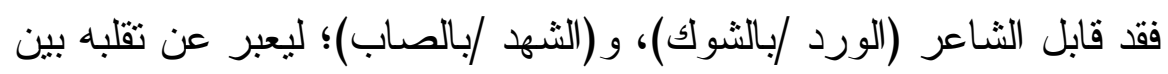

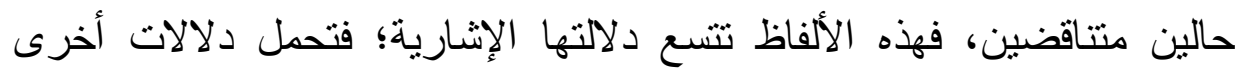

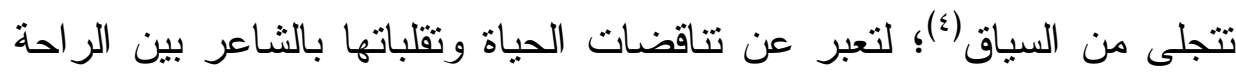
و التعب، فهي تارة تذيقه النعيم و الهناء، وتارة أخرى الثقاء و التعاسة، فأنا

$$
\begin{aligned}
& \text { ( (1) بناء الأسلوب في شعر الحداثة - النكوين البديعي - د. محمد عبد المطلب ، ( م. س)، }
\end{aligned}
$$

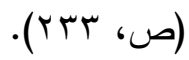

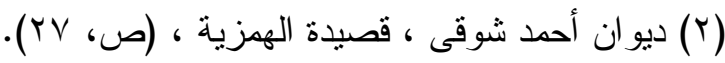

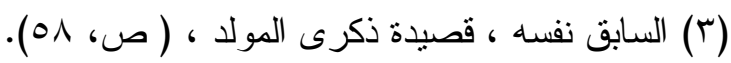

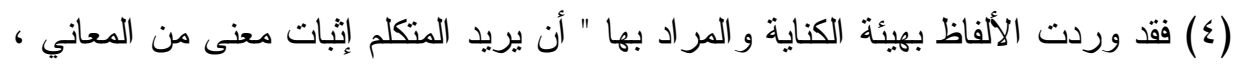

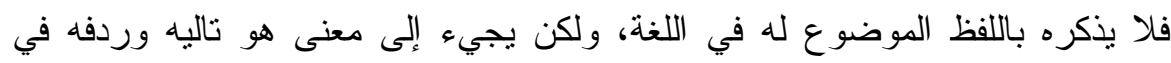

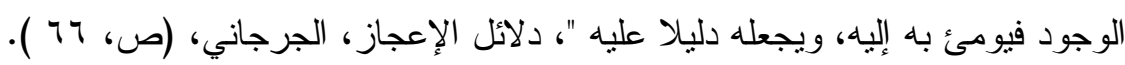




\section{د. • عبيز إسحق محمد حسين لس}

الثاعر هي محور هذه الثنائية ولعل التوازن الموجود بين شطري البيت يعكس توازن الشاعر النفسي، فهو الحكيم المجرب لحالات الدهر المتقلبة .

$$
\text { أيضا قوله:( ) }
$$

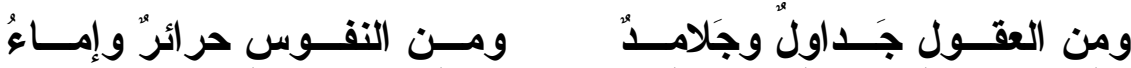
فقد قابل الثناعر ( الجداول / بالجلامد ) وقابل ( الحرائر / بالإماء )، فارتسمت صورة من خلال هذه الألفاظ لتتوع العقول ولتتوع النفوس، فالمعنى الضمني المشار إليه أن العقول المتفتحة مقابل العقول المتحجرة، و النفوس الحرة الأبية مقابل النفوس الضعيفة الذليلة، فهي كنايات تؤكد المعنى وتزده جمالاً، يقول عبد القاهر الجرجاني مؤكداً ذلك " ليس المعنى إذا قلنا إن الكناية أبلغ من التصريح أنك لمَّا كنيت عن المعنى زدت في ذاته ، بل المعنى أنك

$$
\text { زدت في إثباته، فجعلته أبلغ و آكد و أثند"(؟). }
$$

ع - تقابل الإيجاب والسلب : وفيه نأني إحدى اللفظتين مثبتة والأخرى منفية، ويتم ذلك بزرع أدوات النفي المألوفة التي تحيل التماتل إلى تخالف، وقد استععل الثاعر من أدوات النفي ( لا - ما - لم - غير )(ז)، ومن ذلك قوله

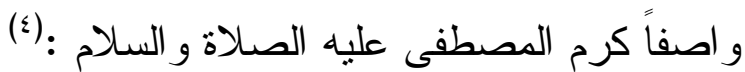

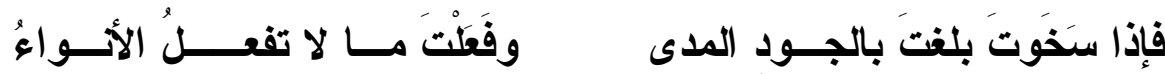

فهذا التقابل الفعلي بين ( فعلت / ولا تفعل ) صوَّر جود النبي (عليوسلهم ) وسخاءه، فقد بلغ جوده أقصى الدرجات و أعلى المر اتب، فلا يصل إلى سخائه أحد؛ حتى النجوم الدالة على سقوط الأمطار -

$$
\text { ( ( ) ديو ان أحمد شوقي ، الجزء الأول ، قصيدة الهزية ، (ص، · ب). }
$$

(Y) دلائل الإعجاز ، عبد القاهر الجرجاني ، تعليق محمود محمد شاكر ، مطبعة المدني

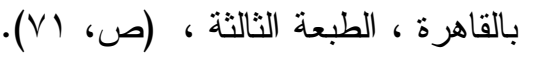

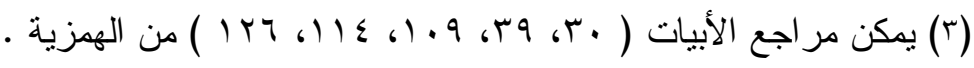

$$
\text { ( ) ديو ان أحمد شوقي ، قصيدة الهمزية ، (ص، (YV). }
$$




\section{البناء التقابلي}

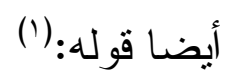

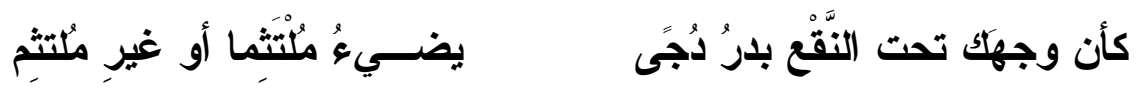

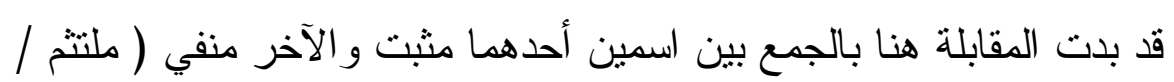

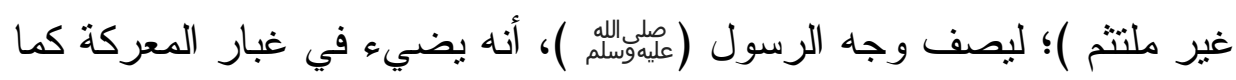

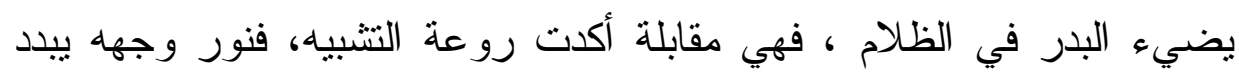

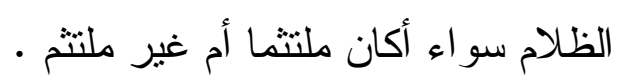

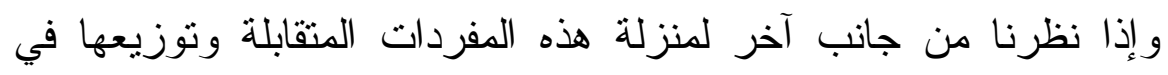

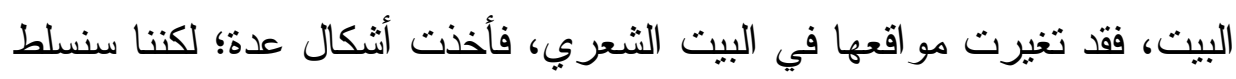

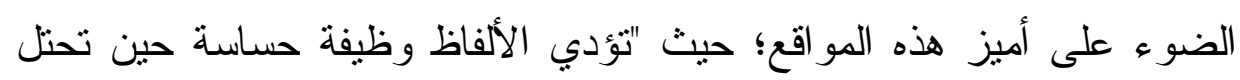

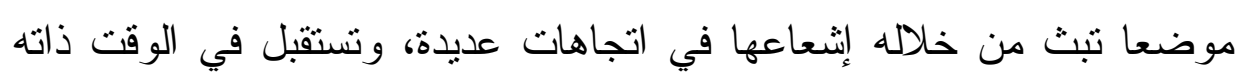
إثنعاعات تلاك الاتجاهات المختلفة"(ب).

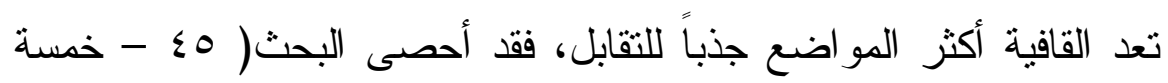

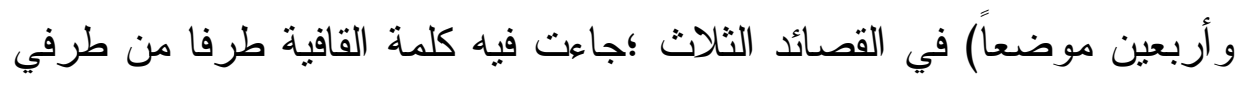

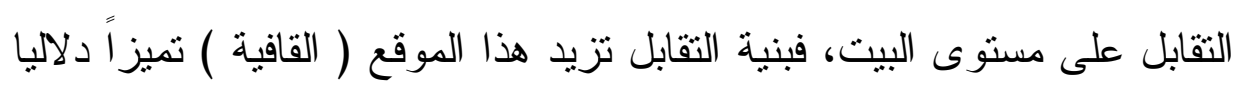

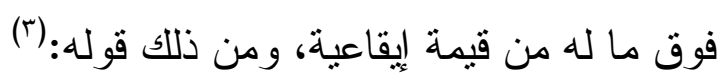

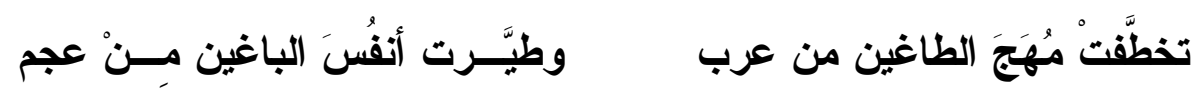

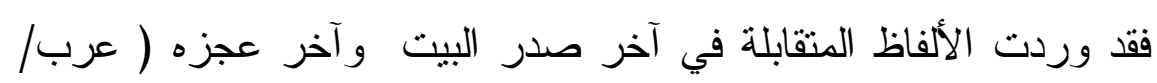

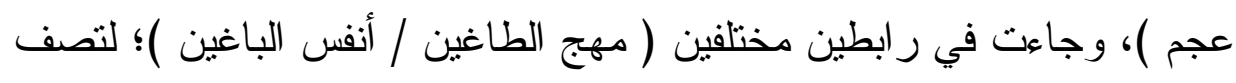

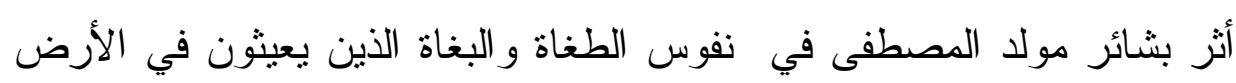

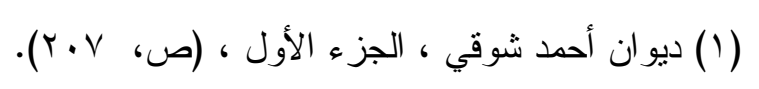

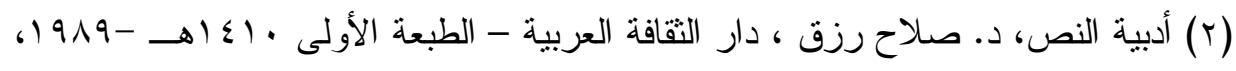

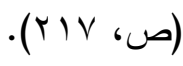

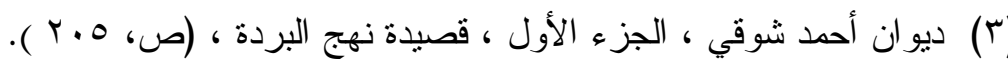

$$
\begin{aligned}
& -00 .-
\end{aligned}
$$




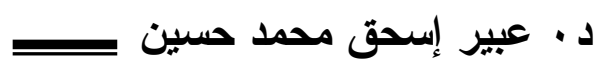

فساداً، و المتجاوزين لحدود الله من العرب و العجم على حد سواء، وكان لوحدة الصورة النحوية بين الثطرين أثز كبير في رسوخ المقابلة التي تعكس مدى الثر و الظلم المستشري قبل مولد الرسول الكريم، فهذا التواشج بين التوازن و التقابل له أثز جمالي، إذ بدل على تلازم المعاني فبمجرد ذكر معنى من مولن المعاني يستدعي المعنى المضاد له، إضافة إلى أنه شكل نوعاً من الانسجام

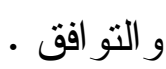

ونلاحظ أيضا كثرة إير اد ألفاظ التقابل متجاورة في القافية، فقد أحصى البحث (ب ا ثلاثة عشر موضعاً )، وردت فيها ألفاظ التقابل متجاورة في القافية، ('): كقوله

\section{بشائرُه البــــــو ادي و القصـــــابـا}

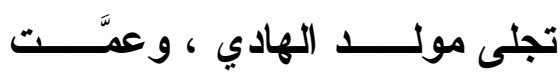

فالتقابل المكاني بين البوادي الدالة على الصحاري ويريد هنا الأرض لهوبل القريبة، وبين القصابا وهي الأرض المنزرعة، ويريد هنا الأرض البعيدة، هذا التقابل يبرز أن حدث و لادة المصطفى لم يكن حدثاً عادياً فقد ظهرت آثناره في الأرضي

$$
\begin{aligned}
& \text { العالم أجمع سو اء القاصي منها و الداني . } \\
& \text { و أيضا قوله : (r) }
\end{aligned}
$$

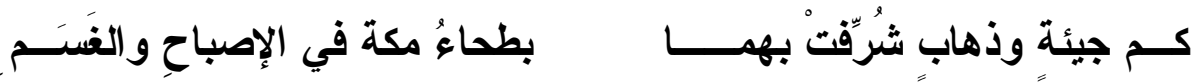

فكلمات القافية ( الإصباح و الغسم ) مرتبطة دلالياً بصدر البيت ( كم جيئة

وذهاب ) و هي مقابلة تكاملية تكثف عن حال رسول الله (علملوسلله ) في ذهابه

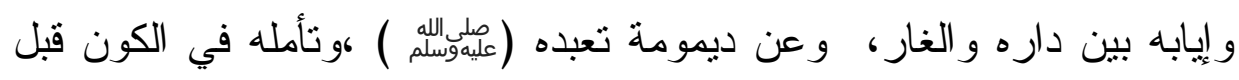

$$
\begin{aligned}
& \text { (1) ديو ان أحمد شوقي ، شوقي ، الجزء الأول ، قصيدة ذكرى المولد ، (ص، (ب). }
\end{aligned}
$$

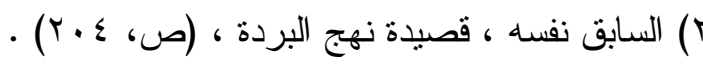

$$
\begin{aligned}
& -001-
\end{aligned}
$$


أما النوع الثاني من التقابل اللغوي فهو التقابل المركب : و المقصود به

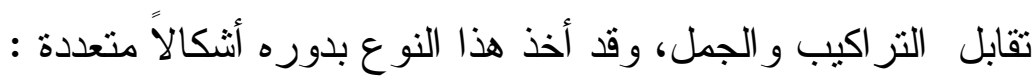

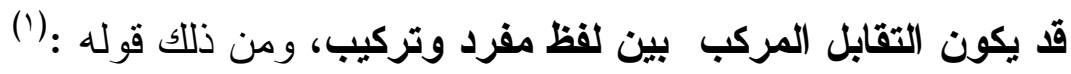

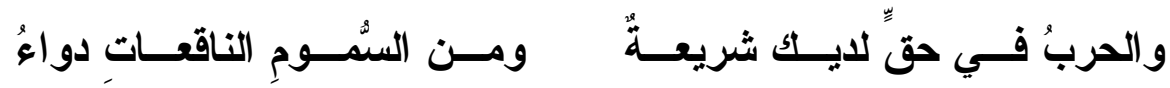

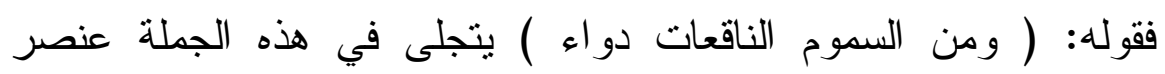

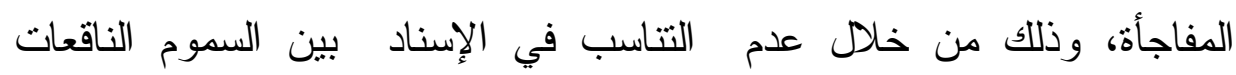

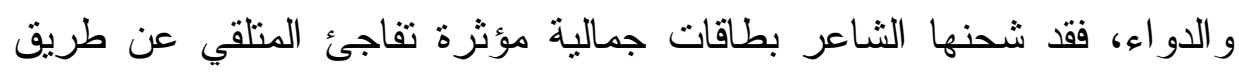

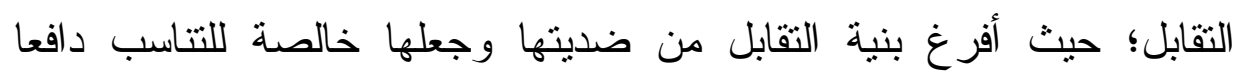
الطرفين إلى حالة من التداخل.

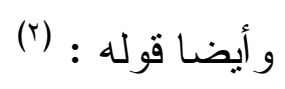

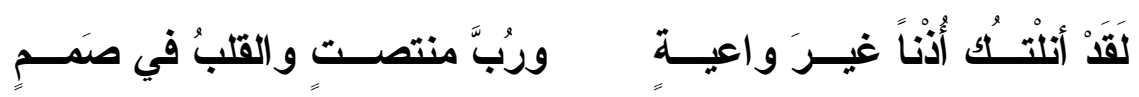

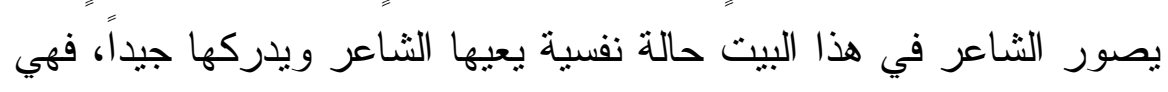

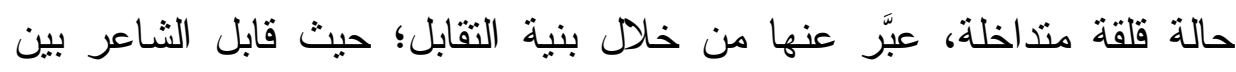

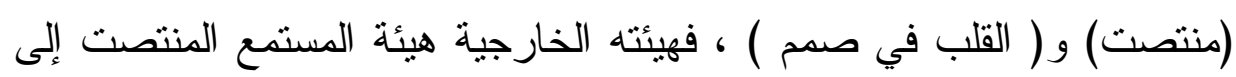

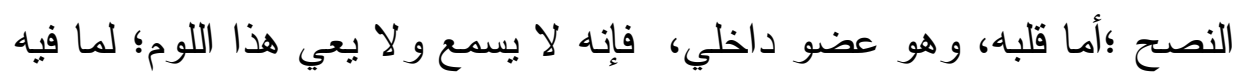

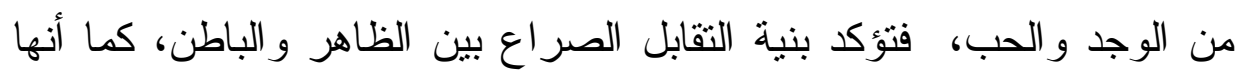

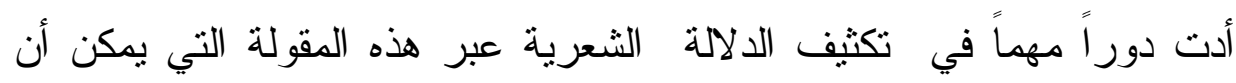

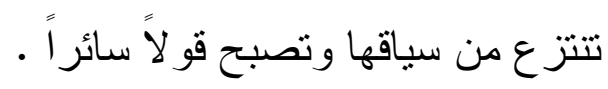

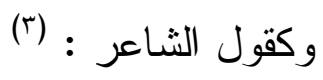

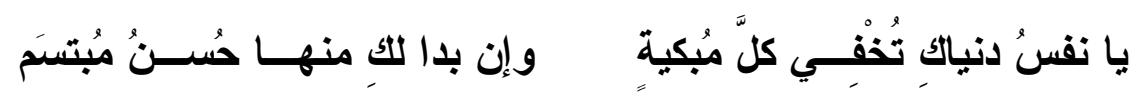

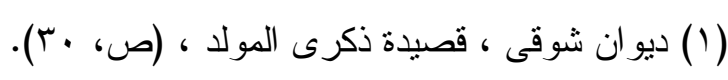

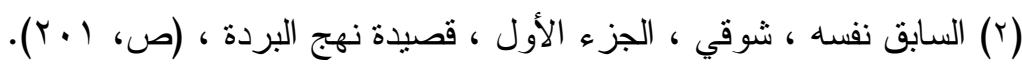

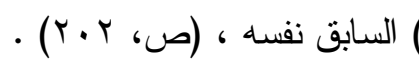

$$
\begin{aligned}
& \text {-00Y- }
\end{aligned}
$$




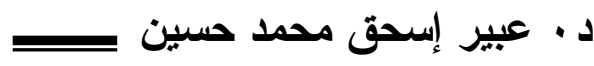

قابل الثـاعر بين كلمة ( مبكية )، وبين ( حسن مبتسم )؛ ليعبر عن فلسفة حياتية مفادها، إن الحياة تغري الإنسان بجمالها وبريقها الخادع الذي ما يلبث أن يتكثف عمَّا يبكي ويحزن، فيكثف بهذا التقابل عن مفارقات الحياة و عجائبها.

وقد يكون التقابل المركب بين تركيب وتركيب ، ومن ذلك قوله:(')

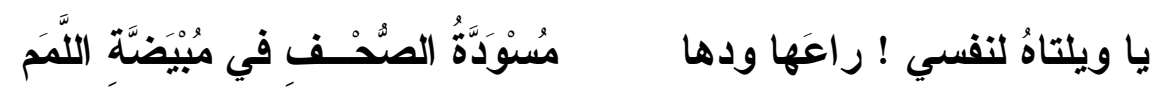
لقد حاول الثاعر من خلا هذا التقابلي اللوني بين ( البياض و السو اد ) أن يندب نفسه التي انغمست في الملذات و الر أس الذي اثتعل شيبا، فقوله ( مسودة الصحف ) كناية عن قلة العمل، وقوله ( مبيضة اللمم ) كناية

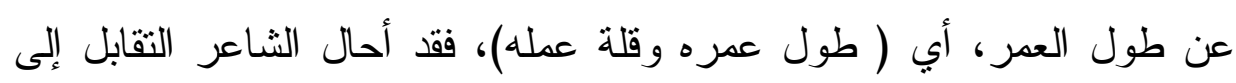
تداخل يكثف عن المتتاقضات المتداخلة في الذات البشرية المتمنلة هنا في ذاتية الثاعر ، فكانت لبنية التقابل دور في تكثيف الدلالة الثعرية . ومن هذا النوع أيضا قوله: (r)

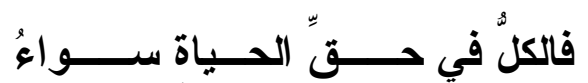

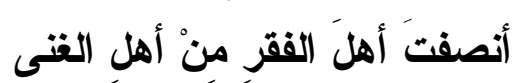
فالتقابل بين (أهل الفقر) و(أهل الغنى) يحيل على وضعين اجتماعيين متقابلين حقق بينها الرسول العدالة الاجتماعية، فالجميع له حق الحياة الكريمة

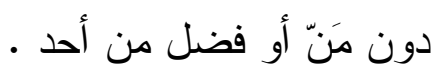

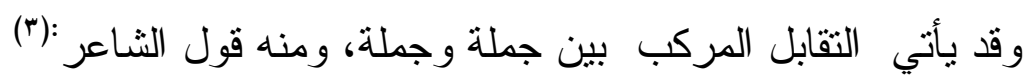

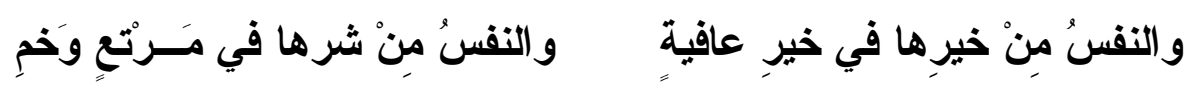

$$
\begin{aligned}
& \text { (1) ديو ان أحمد شوقي ، الجزء الأول ، قصيدة نهج البردة ، (ص، r · r). }
\end{aligned}
$$

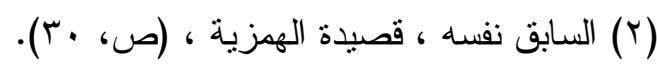

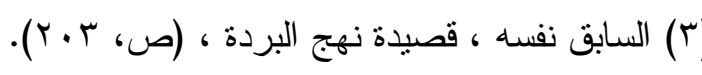

$$
\begin{aligned}
& \text {-oor- }
\end{aligned}
$$


يؤكد الثاعر في هذا البيت حكمة مفاداها، أن الجزاء من جنس العمل،

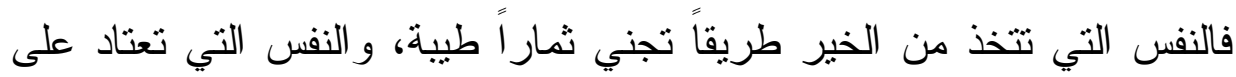

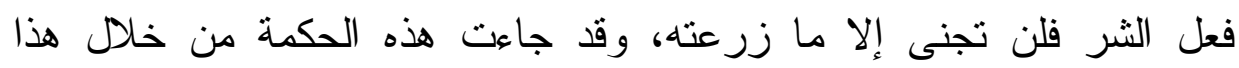

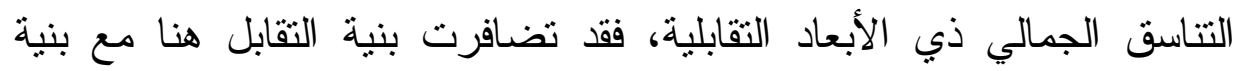

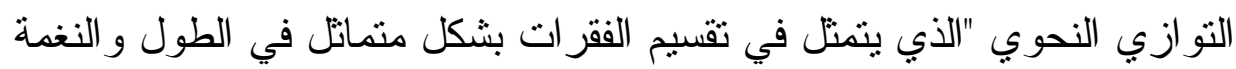

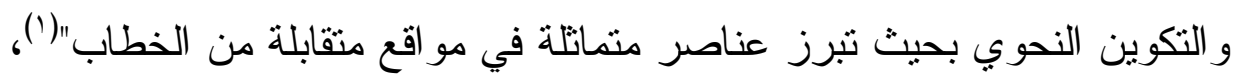

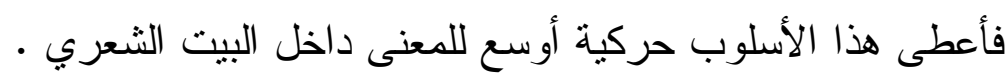

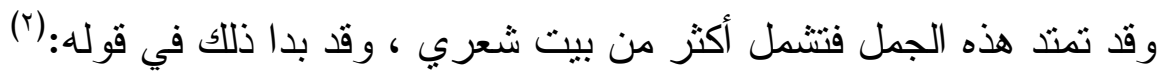

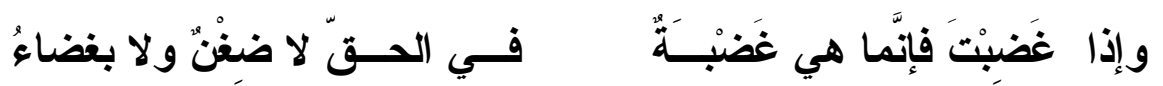

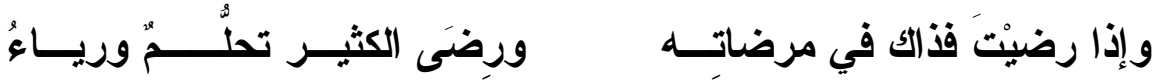

يرسم الثاعر في البيتين صورة ذات وجهين متقابلين متكاملين في آن

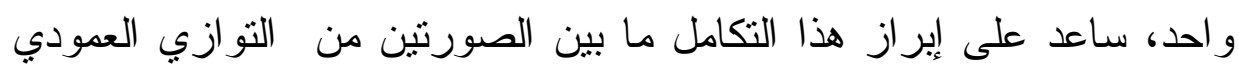

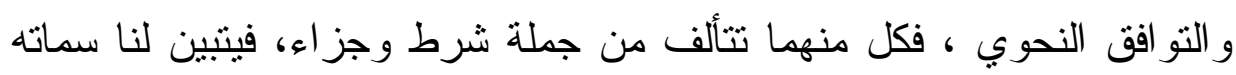

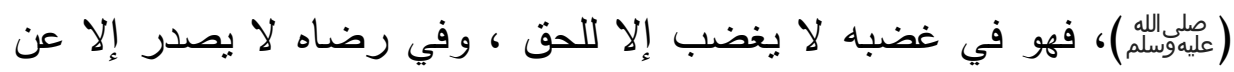
صدق فطري بعيد عن التكلف ، فهذه التقلابات المتكاملة عملت على تكامل النص وتتامي دلالته المعنوية .

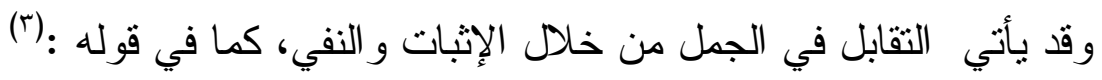

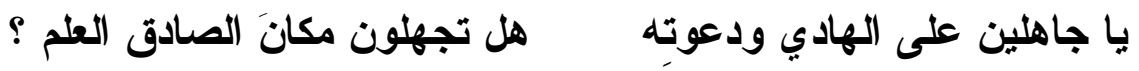

(1) بلاغة الخطاب وعلم النص ، د. صلاح فضل ، الكويت - المجلس الوطني للثقافة

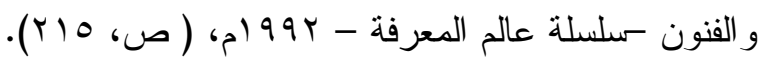

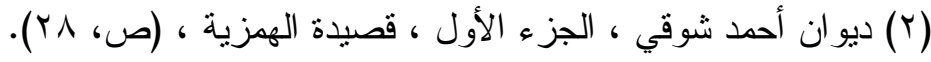

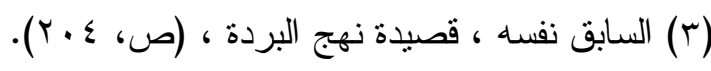
$-00 \leqslant-$ 


\section{دـ ـ عبير إسحق محمد حسين عـ}

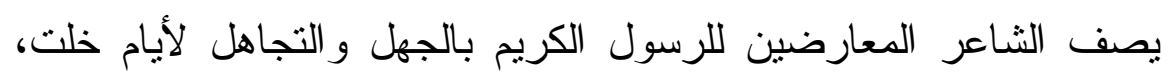

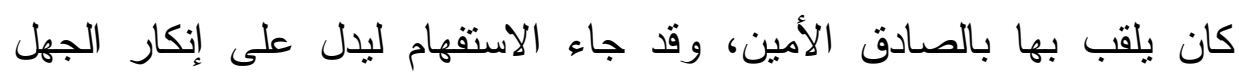

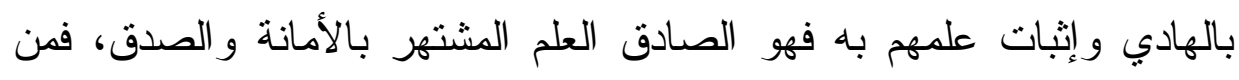

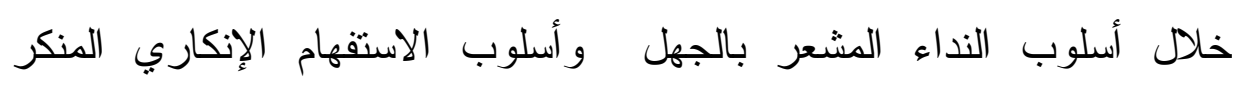

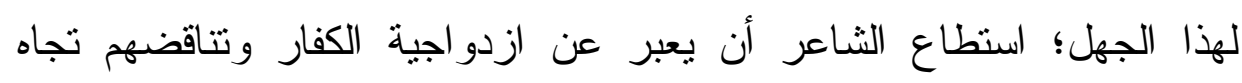
- الرسول وقد ياتي النقابل بين الجمل من خلال الخبر و الإنشاء الذي اتسم بالنفي،

كما في قوله:(') وفئل

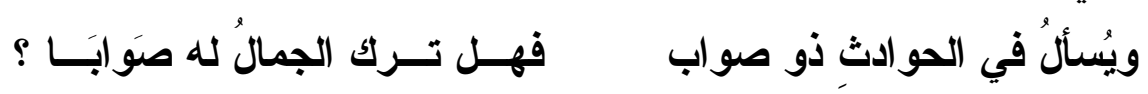
فقد جاءت بنية التقابل بين الخبر والإنشاء؛ حيث يشي أسلوب الاستفهام

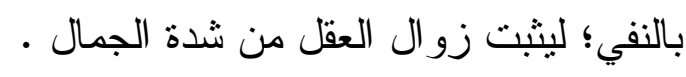

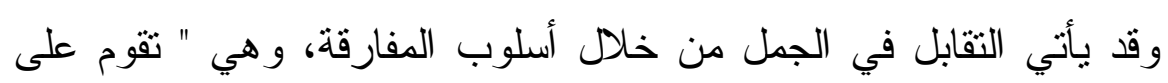

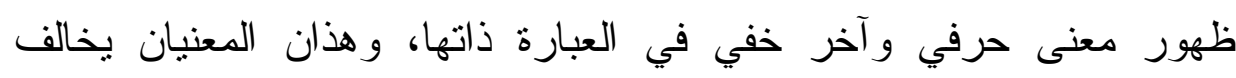
أحدهما الآخر ، وهذا المعنى الخفي لا يكتشف بغير تأمل وتدقيق المر امي "((؟). ومن ذلك قوله: (r)

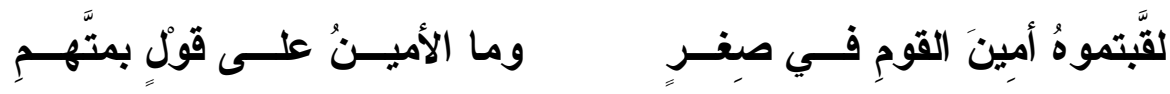

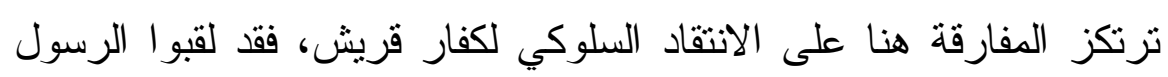

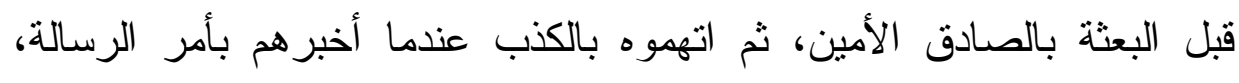

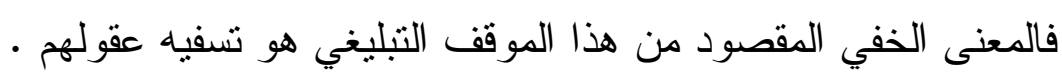

$$
\text { ( (1) ديو ان أحمد شوقى ، قصيدة ذكرى المولد ، (ص، مهن). }
$$

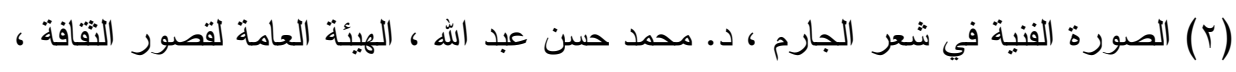

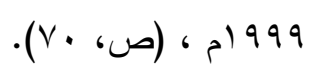

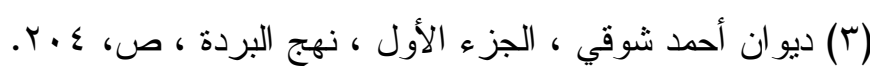


وقد يأني هذا التقابل في معنى المعنى، أب في الصور المجازية؛ حيث

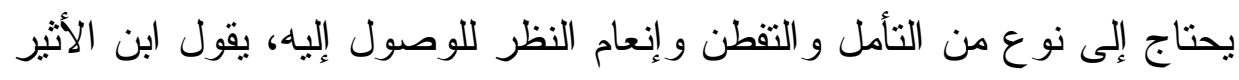
مؤكدا ذلك : " و اعلم أن في تقابل المعاني بابا عجيب الأمر، يحتاج إلى تأمل

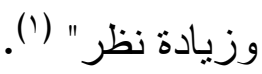

ومن ذلك قوله: (َ)

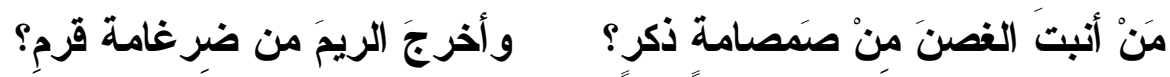

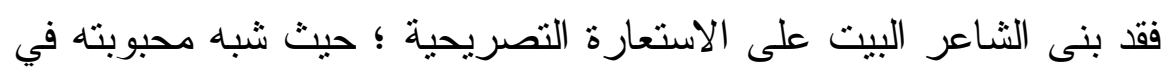

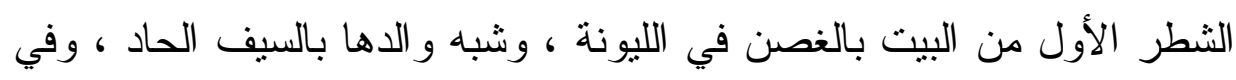

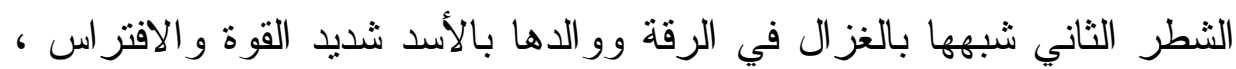

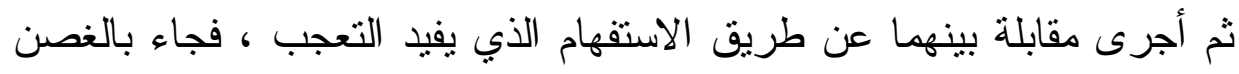

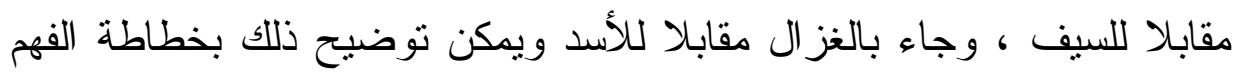

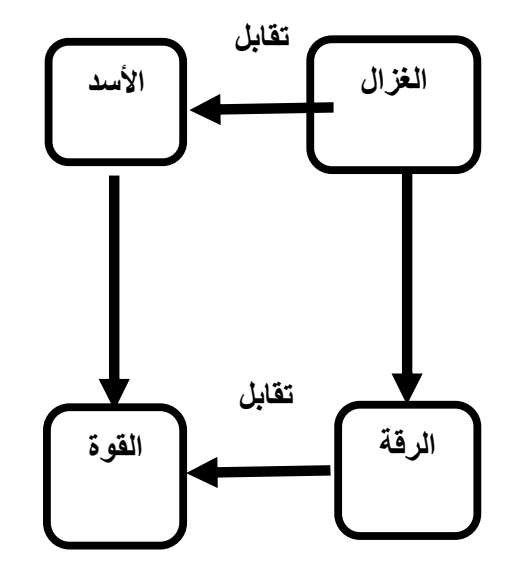

و التقهيم الآتية :

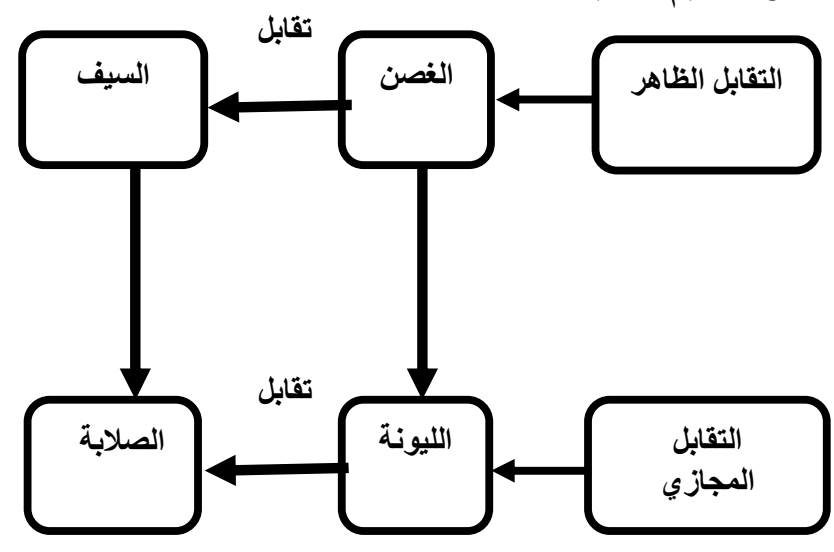

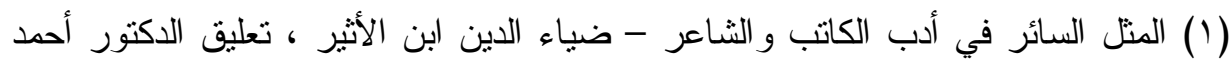

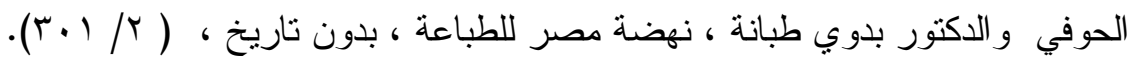

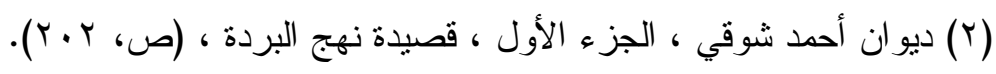




\section{د. • عبيز إسحق محمد حسين لس}

فهذه المقابلة التي عقدها الثاعر أكسبت الاستعارة التصريحية عمقا، وجعلتها أشند ثأثنير ا على المتلقي.

وبهذا تعد بينة التقابل اللغوي وسيلة للإفهام والإيضاح وتكثيف الدلالة الثعرية، كما أنها أضفت على النصوص جمالية أسلوبية من خلال تضافرها مع البنى البلاغية الأخرى . المحور الثاني :التقابل الخطابي : و المقصود به "تقابل الذوات في مقام الخطاب و أوضاعها الاعتبارية التابعة لذلك "(')، فهو تقابل مؤطر لبنية النص ذو طبيعة تو اصلية خطابية، ويتبلور هذا النوع في الخطاب الثعري عبر تواجه الذوات المعبر عنها بالأسماء أو بالضمائر، وسنسلط الضوء هنا على التقابلات المركزية البانية للمعنى و المحققة للمقاصد الكلية لخطاب المديح النبوي المرنبط بمكانة المرسل إلبه ومقامه. فمن الثقابلات البانية للخطاب، التقابل بين (الذات المادحة - الثاعر) و (الذات الممدوحة -الرسول عليوللهم ) على مستوى الخطاب، وقد حضر هذا التقابل بقوة في نص (الهمزية النبوية)؛ حيث جاء هذا التقابل أثببه بالعمود الفقري للنص، فقد اعتمد الثاعر بصفة رئيسة في هذا النص على ضمائر المخاطب المحيلة إلى موضوع الخطاب (الرسول عليولسلم )؛ لتقديم صورته (علملوسله ) (بوصفه مبعوثا ومبلغاً لرسالة السماء هذا من جانب، ومن جانب آخر بوصفه إنساناً وقائداً ومعلماً. فقد حضرت شخصية الرسول في فضاء النص الثعري من خلا الكلمات التالية: (الهدى، محمد ،طه، اليتيم، الأمي ، الهادي ، ابن عبد الله، المسرى، أحمد، رسول الله) فهذا التوظيف النوعي لاسم النبي عليهولسلم يبرز الخصال و الصفات و الأدو ار التي قام بها .

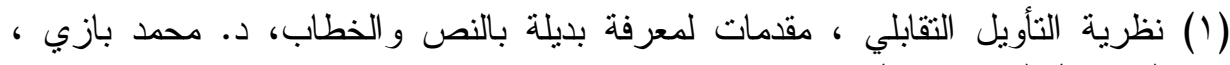

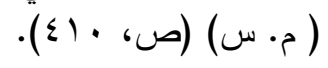


كما تتو اجه (الذات المادحة) مع (الذات الممدوحة) عبر أبيات تكثف عن

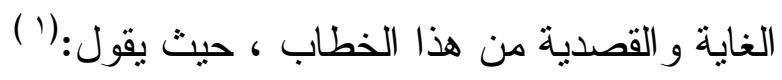

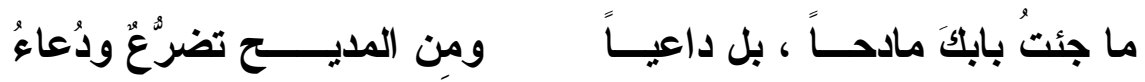

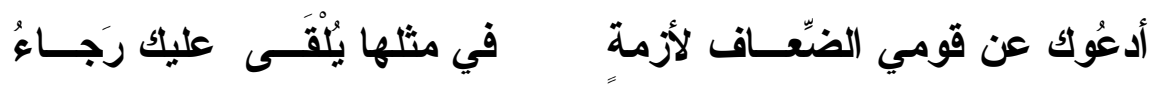

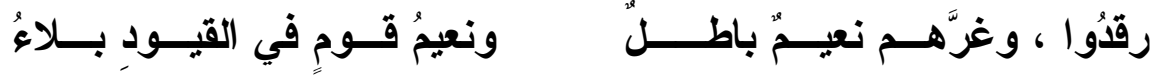

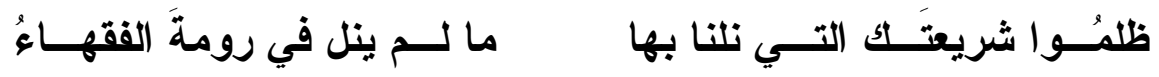
وقد جاء هذا التقابل بنبرة استعطافية تضرعية تراعي مقتضى الحال، ومقام المخاطب ،ووضعه الاعتباري، فكثف هذا التقابل عن هوية هذا الخطاب لئل

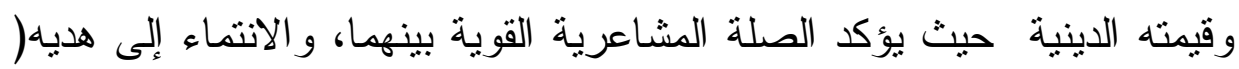

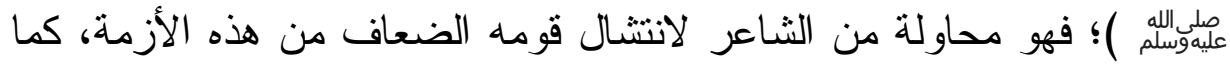

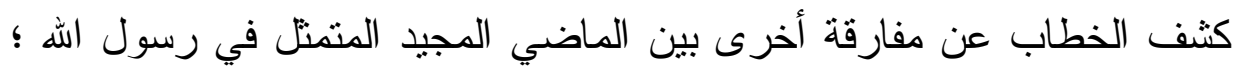

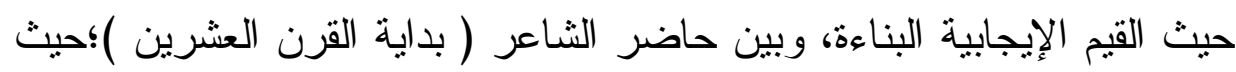

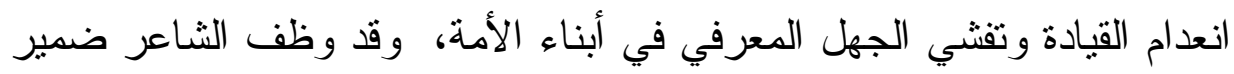

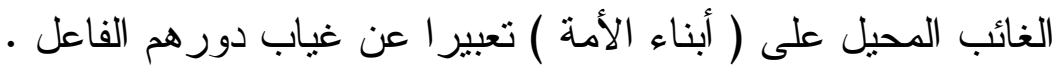

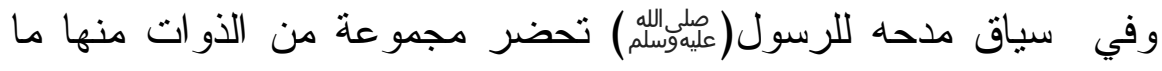

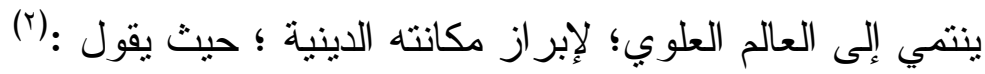

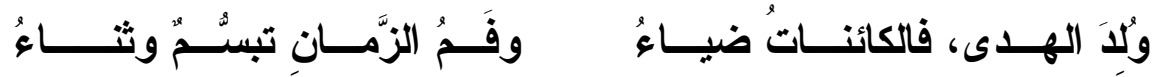

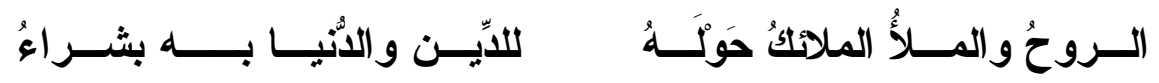

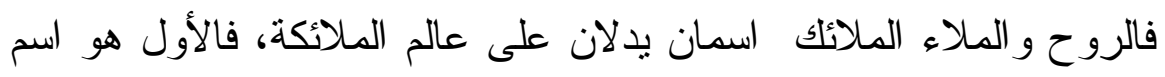
جبريل منزل الوحي على الرسول الأكرم، و الثاني اسم يدل على على عموع الملائكة

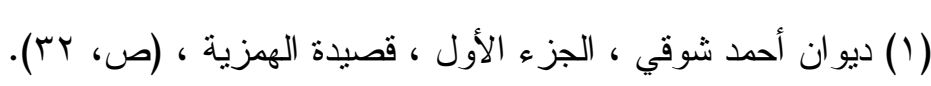

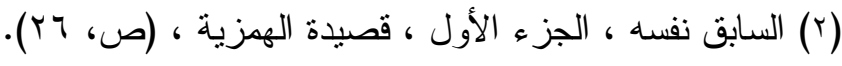

$$
\begin{aligned}
& -001-
\end{aligned}
$$




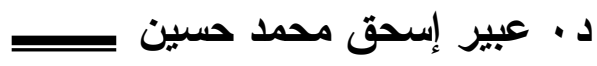

الذين يقودهم جبريل في ذهابه و إيابه أثناء تأدية مهمته، و أنهما من العالم العلوي الإلهي مكلفان بمهة رعاية صاحب النبوة في العالم السفلي الدنيوي • كما عقد الثاعر في فضاء الخطاب مقارنات متعددة بين الرسول وبين نظر ائه من الرسل، وهي مقارنات قائمة على مبدأ التفاضل و التمايز، ومن ذلك على سبيل المثنال قوله: (1)

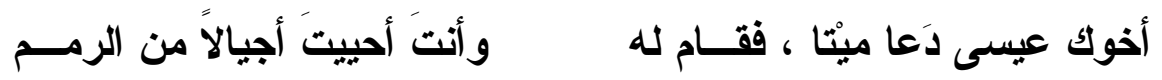
فإذا كانت رسالة عيسى عليه السلام إلى بني إسرائيل فقط ، ومعزته إحياء الموتى بإذن الله ؛ فإن الثريعة التي جاء بها الرسول الأكرم للبشرية جمعاء، و استعار الثاعر كلة " الرمم" للقيم المتخلفة التي كانت تسود الناس قبل الرسالة المحمدية.

$$
\text { و أيضنا قوله: (r) }
$$

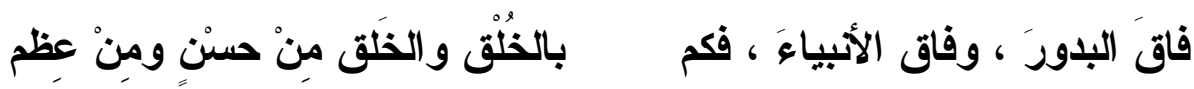

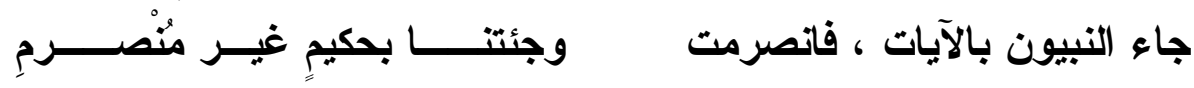
فقد أثنار الثاعر إلى اكتمال الصفات الجسدية والخلقية للرسول عليهوسلمه، وتفضيله وتميزه على سائر الأنبياء بمعجزة القرآن الخالدة المتجددة، فقد تعهده الله بحفظه

أيضا أجرى الثاعر في فضاء الخطاب مجموعة من المقارنات السلوكية الأخلاقية القائمة على التمايز و المفاضلة بين الرسول الأكرم وسائر البشر من ذوي الأخلاق و العلم و الفصاحة العالية، موظفا فيها أسلوب النداء الدال على ولى المكانة و العظمة العالية للمصطفى( عليهولسله )، ومنها على سبيل المثال قوله:(r)

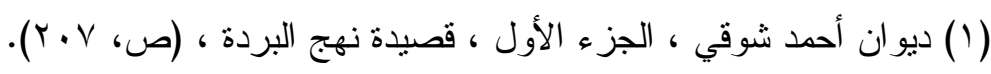

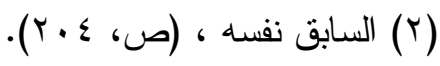

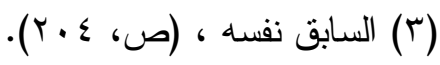




\section{البناء التقابلي}

يا أفصحَ الناطقين الضادَ قاطبة"

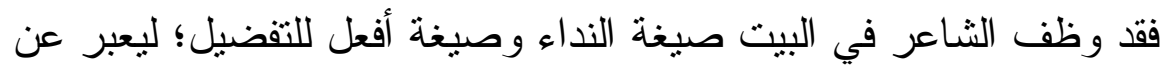

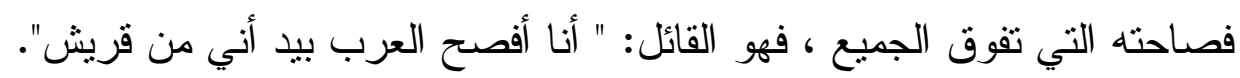

وأيضا قوله : (1)

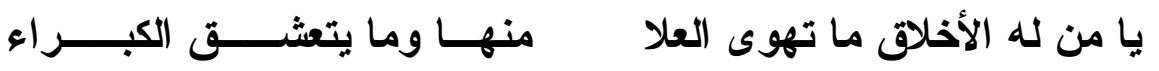
فالرسول يفوق جميع البشر في خلقه، فهو القدوة والمثل الأعلى للكمال

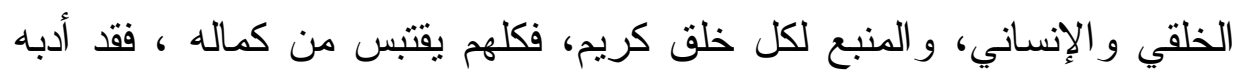
ربه فأحسن تأديبه.

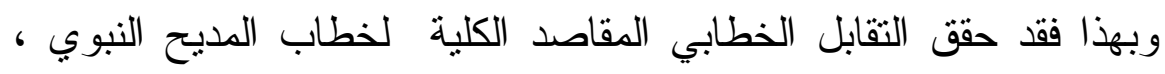
المرتبط بمكانة المرسل إليه ومقامه، و المر اد إبلاغها إلى المتلقي .

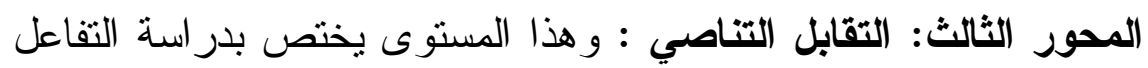

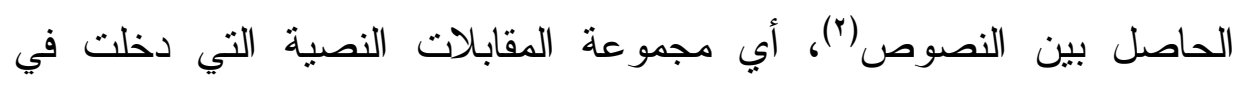

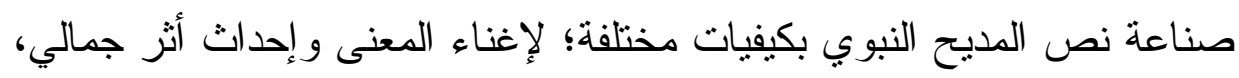
فأي نص " يرتبط بمجمو عة من الدقابلات القبلية الني يستقيد منها جزئياً أو كلياً أو وفق أي علاقة من علاقات الاستلهام، أو الأخذ، أو التفاعل تدخل فئل فئها الدقرو ءات السابقة للمؤلف، و النصوص التي اطلع عليها قاصداً استثمار ها "(() .

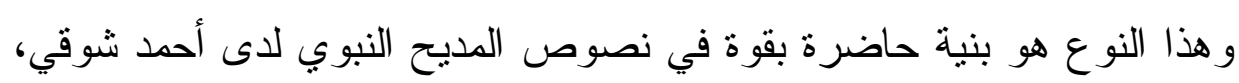

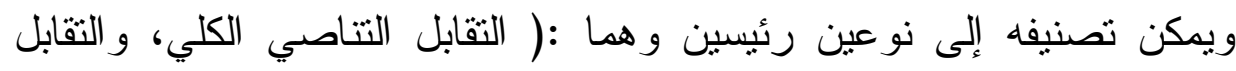
التناصي الجزئي ).

$$
\text { ( ( ) ديو ان أحمد شوقى ، قصيدة الهمزية ، (ص، YV (Y). }
$$

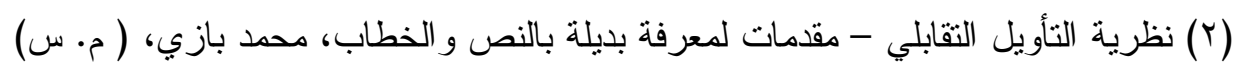

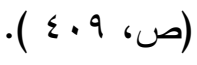

$$
\begin{aligned}
& \text { ( السابق نفسه ، (ص، ع (ب ). }
\end{aligned}
$$


د. عبير إسحق محمد حسين

التقابل التتاصي الكلي : ويقصد به دخول النص في علاقة كلية مع نص سابق عليه، فالنص ينتج ضمن بنية نصية سابقة عليه، فهو يتعالق به ويتفاعل

وقد بدا هذا النوع بصورة جلية في قصيدة" نهج البردة "؛ حيث احتذى

أحمد شوفي حذو "البوصيري" في قصيدته " البردة "، و التي مطلُعها : (1)

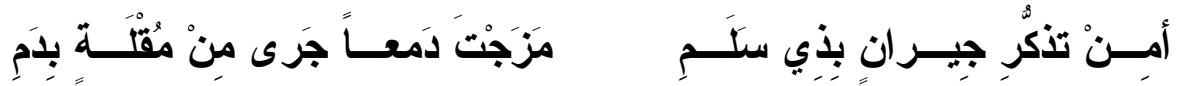

فقد نظم أحمد شوقي قصيدته في (تسعين ومائة بيت - . 19 )، على وزن البسيط وروي الميم المكسورة، ولقبها بــ( نهج البردة )؛ للدلالة على أنها منظومة على نهج نص مصرح به وهو" بردة "البوصيري، وقد أطلق النقاد على هذا النوع من الثعر "المعارضات"، ومصطلح المعارضة يتفق مع ما نحن بصدده وهو "المقابلة" ، فالمعارضة تحمل مفهوم المقابلة، فقد جاء في لسان العرب " عارض الشيءَ بالثيء معارضةً : قابله ، و عارضَضْتُ كتابي بكتابِه أي

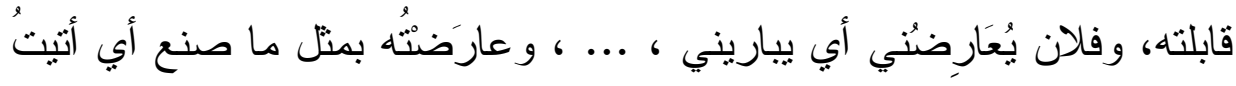

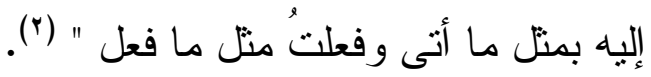

يقول محمد عز ام : " الأصل في المعارضة الشعرية أن ترنكز على غريزة (المحاكاة = المماتلة ) من ناحية و على غريزة) المنافسة =المقابلة ) من ناحية

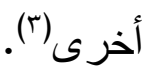

(1) شرح الكواكب الدرية في مدح خير البرية المعروفة بالبردة ،الثيخ إبراهيم الباجوري، حققها وضبطها وعلق عليها الثيخ عبد الرحمن حسن محمود، مكتبة الآداب - ميدان

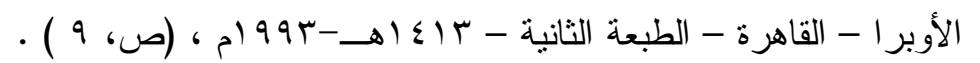

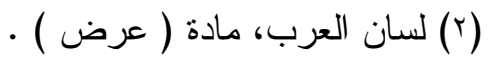

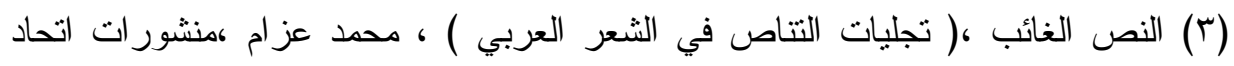

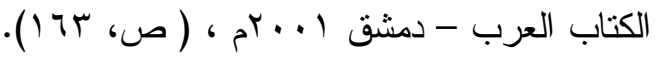




\section{البناء التقابلي}

فأحمد شوقي لم يتوقف عند حدود نص البوصيري؛ بل نجده يتجاوزه بما يؤكد مفهوم المقابلة و المفارقة بين النصين، فعلى مسنوى المعنى العام

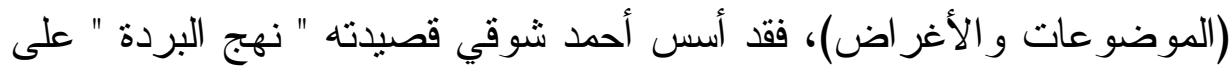

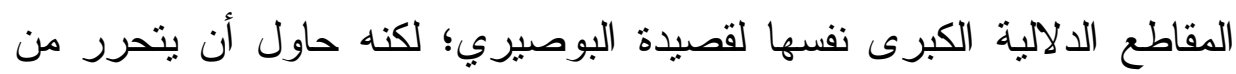

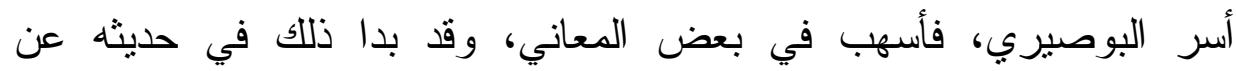

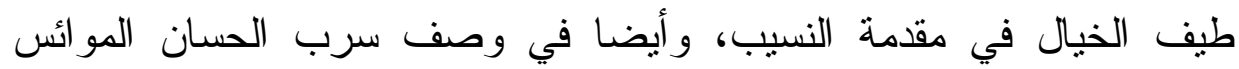
اللائي تتنهي إليه معشوقته ،و انتظم عنده ذلك في أربعة عشر بيتا، و التي تبدأ (1): بقوله

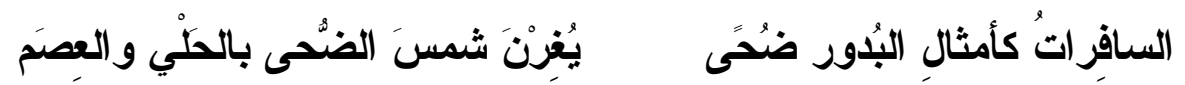

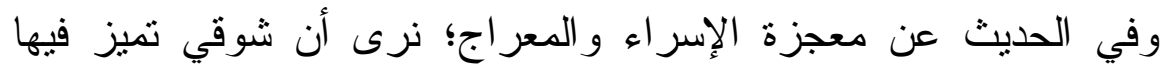
بحديثه عن البراق، كما تفرد شوقي بمقارنة الحضارة الإسلامية بالحضار ات اتلات القديمة، وبخاصة الحضارة الرومانية واليونانية وحضارة مصر القديمة، وتقرد

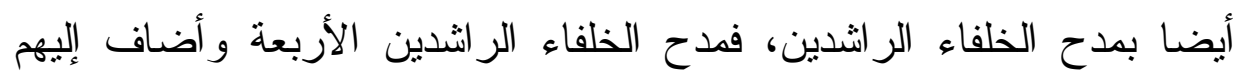

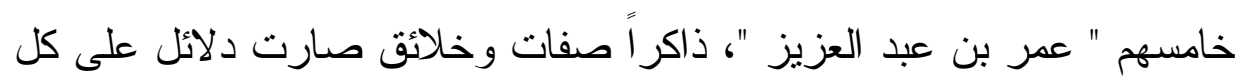

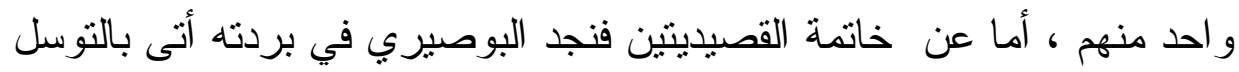

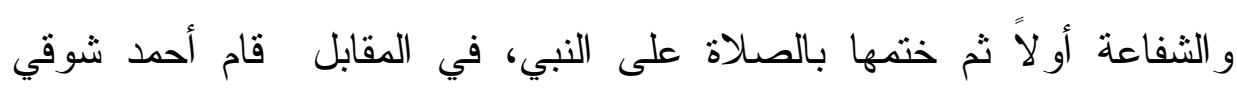

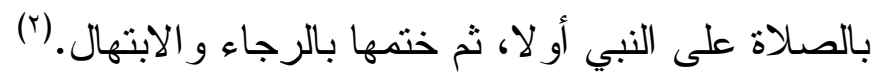

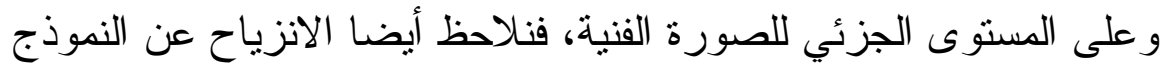
المقابل، فبرغم إلتقاء الثاعرين في أبيات عدة؛ فإن لكل منهما صياغته لفئه

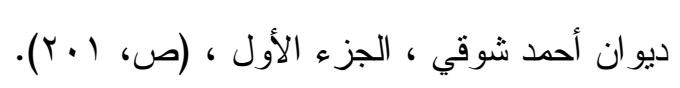

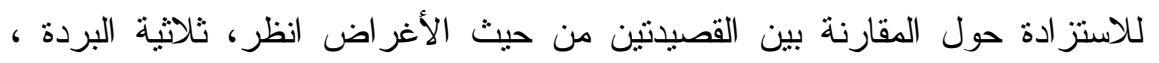

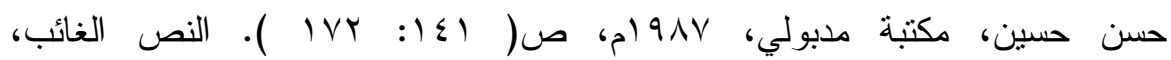

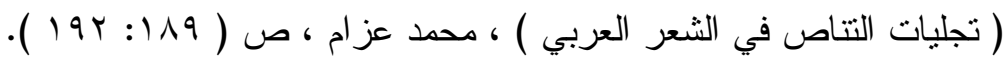

$$
\begin{aligned}
& -07 r-
\end{aligned}
$$




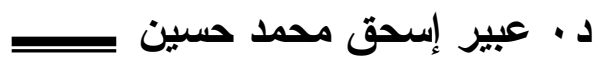

الخاصة، وسأكتفي هنا بعرض بعض الأمنلة الدالة على ذلك، فمن مظاهر التصرف في التصوير ما نر اه في موضوع التحذير من هوى النفس، حيث اتفق

الخطابان في الموضوع؛ لكنها اختلفا في طريقة التمثيل، يقول شوقي : (')

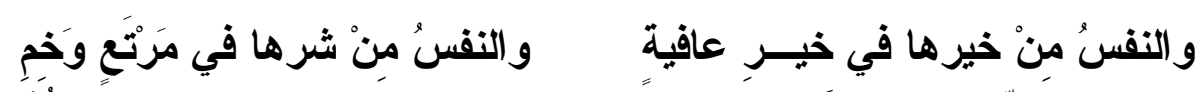

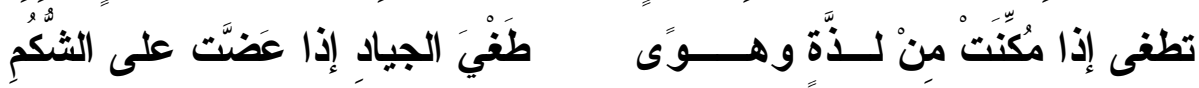

(r): يقابله قول البوصيري

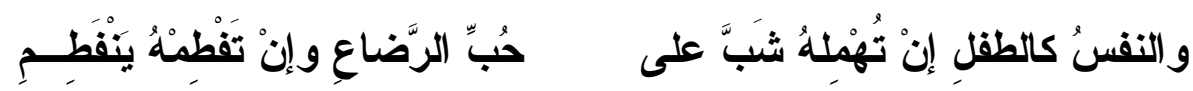
نجد أن الخطابين يتشابهان في الموضوع وهو النفس، إلا أنها يختلفان في طريقة التصوير؛ حيث صور البوصيري حالة النفس التي تترك دون محاسبة بحال الطفل الذي يترك دون فطام، فقد انطلق من القول الثائع بين الناس" من لن لئرئ شب على شيء شاب عليه "، فالتمثيل هنا علامة دالة على الاستسلام و الخضوع ، أما شوقي فقد صور حال طغيان النفس و إسر افها في أبو اب الهوى بحال الجياد التي تعض على الحديدة المعترضة في فمها من اللجام حال ثورتها، فهو ينطلق من فكرة مفادها أن الهوى هو الدافع القوي لكل طغيان، فالتمثيل في

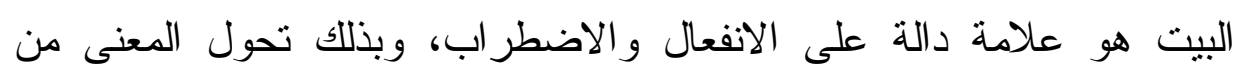
الاستسلام و الخضوع في خطاب البوصيري إلى الانفعال و الاضطر اب في

$$
\begin{aligned}
& \text { خطاب شوقي · } \\
& \text { (r): أيضا قوله } \\
& \text { البدرُ دونكََ في حسنٍ وفي شــرفٍ }
\end{aligned}
$$$$
\text { يقابله في ميمة البوصيري }
$$

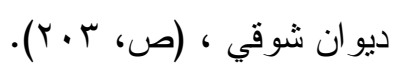

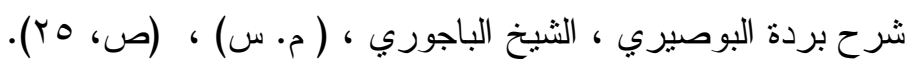

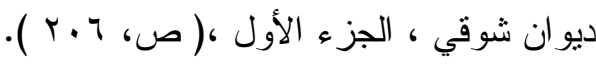

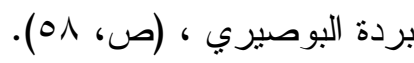




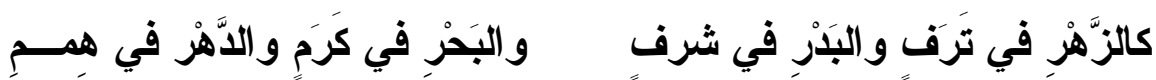

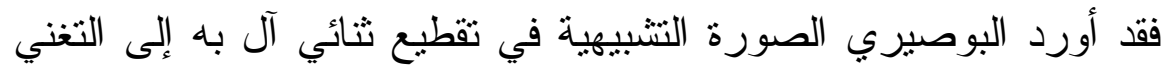

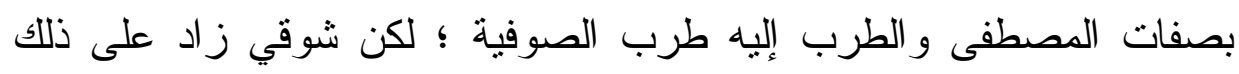

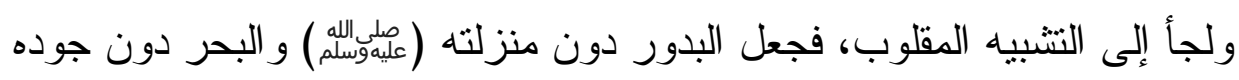

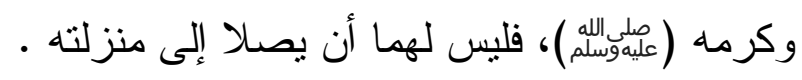

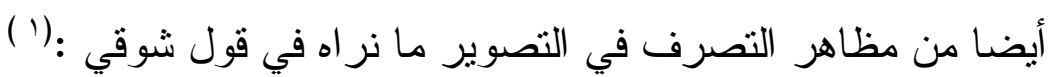

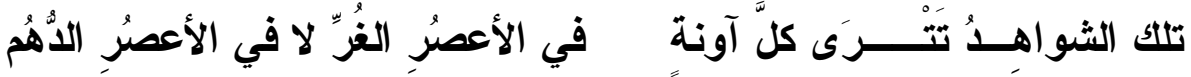

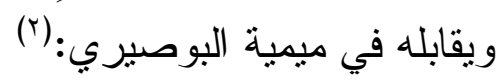

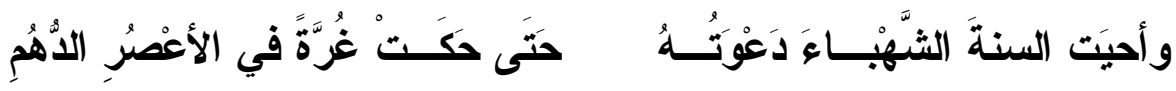
ويلاحظ في بيت شوقي أنه اكتفى بوصف الأعصر بالغر تارة وبالدهم

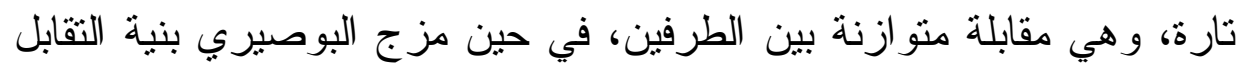

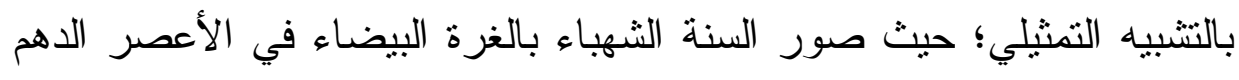

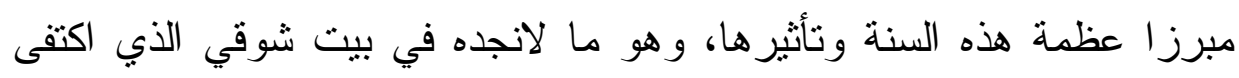

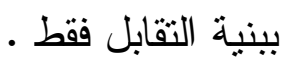
وتجدر الإثارة هنا إلى المقارنة الأسلوبية التي أجراها "د. محمد الهادي

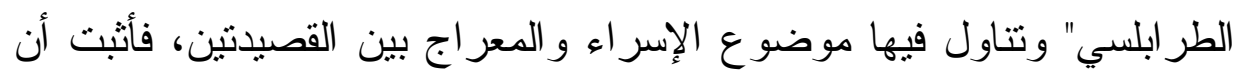

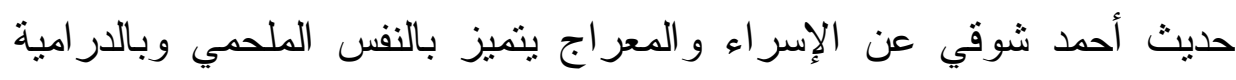

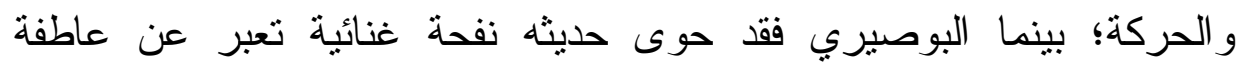

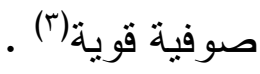

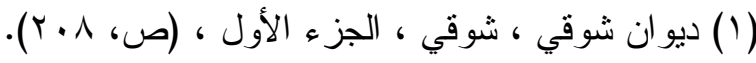

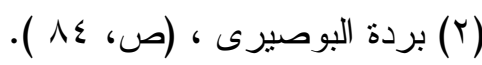

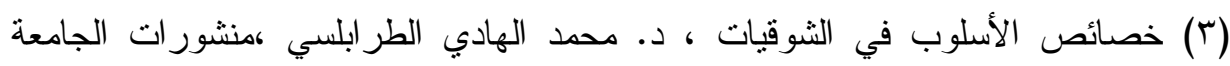

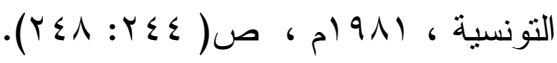

$$
\begin{aligned}
& -0 Y \varepsilon-
\end{aligned}
$$


د · عبيز إسحق محمد حسين لِ

أما على المستوى الأسلوبي العام للقصيدنين، فقد اختبر البحث فرضية " نسبة تتوع المفردات بين القصيدنين "؛ وذللك باستخدام مقياس جونسون" إذ يرى أنه في الإمكان إيجاد نسبة لتتوع المفردات في النص أو في جزء منه، إذا ما حسبنا فيه النسبة بين الكلمات المتتوعة (أي المختلفة بعضها عن بعض)، و المجموع الكلي للكلمات "(')، وقد التزم البحث بالثروط نفسها التي أوردها

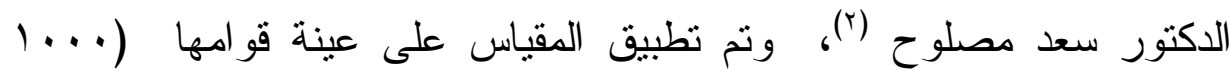
كلمة) من بداية كل قصيدة ، فجاءت نسبة التنوع عند البوصيري ( 0^, • ) ، وعند أحمد شوقي بنسبة ( TV, · ) ، فقد ارتفعت نسبة تنوع المفردات في قصيدة أحمد شوقي بالنسبة إلى قصيدة " البوصيري"، ويرجع ذلك فيما أرى إلى ، أن أحمد شوقي ينتمي إلى مدرسة الصنعة في الثُر ، أما البوصيري فهو شاعر مطبوع يعتمد على الارتجال و التلقائية ؛ مما أدى إلى ذيوع هذه القصيدة وحفظها وسهولة التزنم بها على مدى العصور •

فمن خلال المقابلة السابقة بين النصين يتضح لنا انزياح نص (نهج البردة) عن النموذج المقابل، فقد اختلف النصان في عدد الأبيات؛ حيث حرص أحمد شوفي على التوسع و الإضافة ، وهو ما يؤكد مبدأ المخالفة و الحرص على التقوق من جانبه ، و على المستوى الصورة الجزئية نلاحظ قدرته على إنتاج

(1) في النص الأدبي - در اسة أسلوبية إحصائية، د. سعد مصلوح،عين للار اسات و البحوث

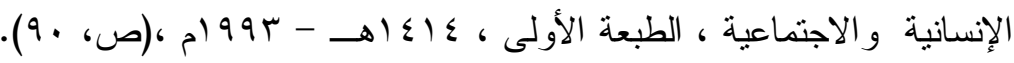

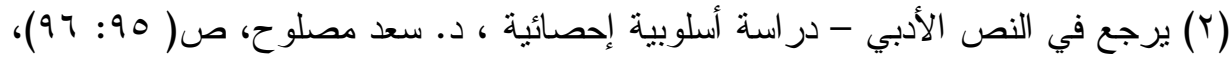
أيضا طبقت الباحثة المقياس نفسه و التزمت بالثروط نفسها في رسالتها للاكتور اه "

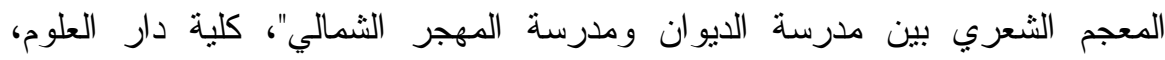
. r : : 1 17 . 
المعاني الجديدة من معطف النص المقابل دون الوقوف عند التقليد فحسب، ثم يأتي اختبار فرضية نسبة نتوع المفردات فيكثف صنعة أحمد شوقي. التقابل التناصي الجزئي : ويقصد به دخول النص في علاقة جزئية مع نصوص سابقة له فهو يتعالق بها ويتفاعل معها، وهو تقاعل يدعو إلى المقارنة و استحضار النصوص الغائبة بشكل مقابل للنص الحالي .

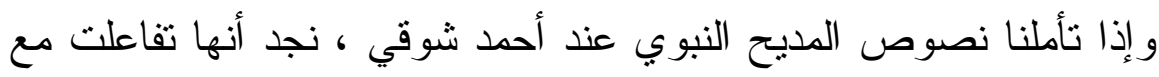
النص القرآني بشكل ملحوظ ديث تحيلنا كثير من الأبيات على النص القرآني المقابل لها، وقد تجلى ذلك في الأبيات التي نتاولت شخصية المصطفى ( عليه

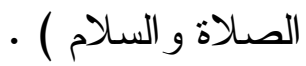

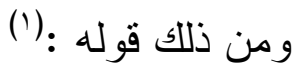

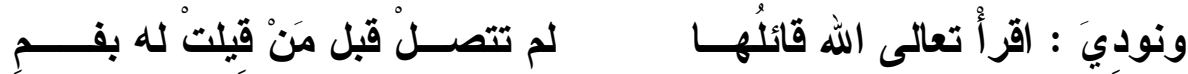

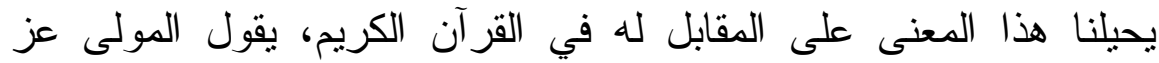

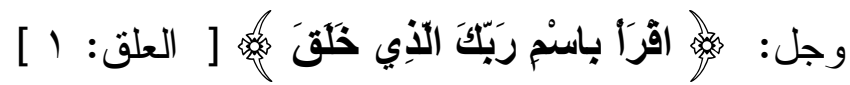
ومن ذللك أيضا : (؟)

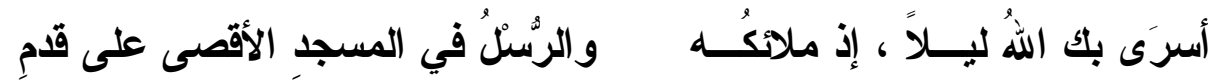
يحلينا هذا البيت بنوع من التقابل التتاصي على ما ورد في القرآن الكريم

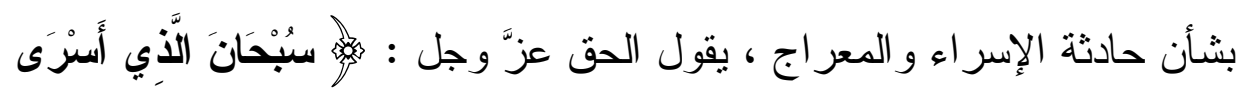

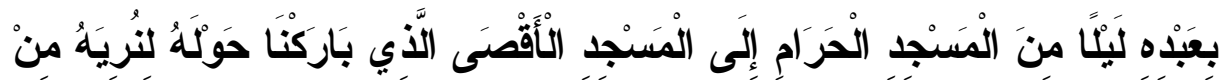

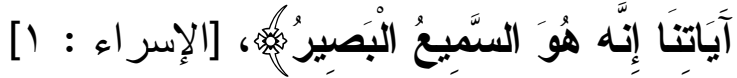

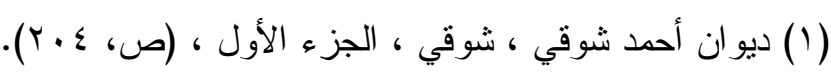

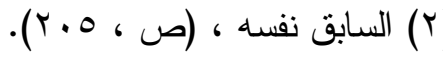




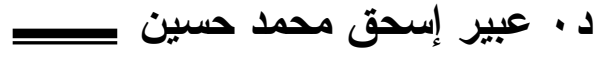

فقد أضفى هذا التفاعل مع النص القر آني على الخطاب الثعري القداسة الروحية التي تتو افق ومكانة الرسول الكريم وعظمته، وعمل على إعطاء مصداقية وتميز للالالة الثعرية ، وذلك استتادا إلى مصداقية النص القرآي

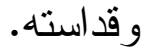

كما تفاعل الثناعر مع أحداث السيرة النبوية، وتجلى ذلك في مواضع

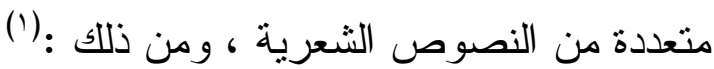

بما حفظتـــا من الأسماء و السبِّمِ

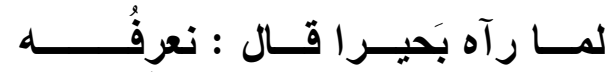

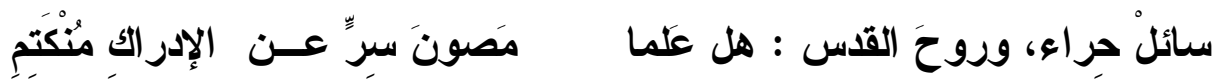
بَطَاءُ مكة في الإصباحِ والغَسَمَ

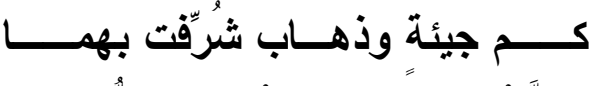

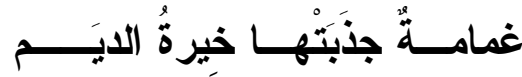

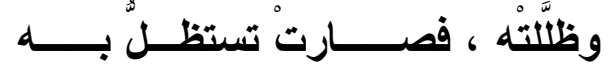

فهذه الأبيات تحيل المتلقي إلى المقابل النصي لها، وهو ما ورد في السيرة النبوية من أحداث ومواقف صادفها الرسول في حياته قبل بعثته، تتبئ بما له من خصوصية تميزه بين خلق الله جميعا، فأثنارت الأبيات إلى ( بحيرى) الر اهب حين رآه وهو صبي في تجارة عمه أبي طالب؛ حيث تعرف عليه بما كان يصاحبه من أمار ات تعلن عنه، جاءت في كتب الديانات السابقة، أيضا ما أثز عنه من تعبده في غار حر اء، و اعتز اله أتزابه و عشيرته بما نشأو ا عليه من عادات وتقاليد ومعتقدات، أيضا ما نتاقله الرو اه من معجزات كنبع الماء العذب من أصابعه ( عليهولسلمه) حين ضـج أصحابه من شدة العطش، وكمصاحبة الغمامة إياه في حله وترحاله، تظلله وتقيه حرارة الثمس (r) .

$$
\text { (1) ديو ان أحمد شوقى ، (ص، ·). }
$$

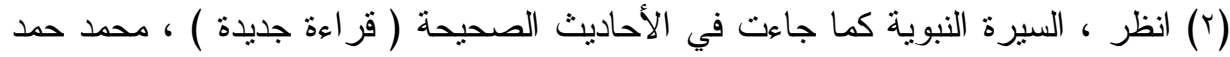

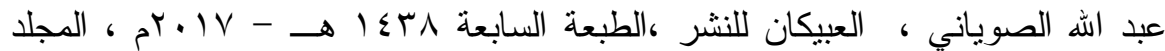

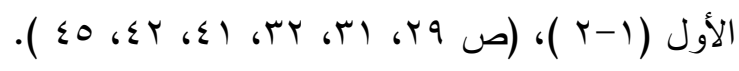


فجميع هذه الإشار ات لها أهميتها وفاعليتها في فهم النص وتحليله، ومعرفة

أبعاده المختلفة، والإحاطة بشعريته، فهي إثنار ات تتكثق حول تيمات تعمق أجو اء القصيدة، فلا يمكن فهم المعنى إلا بعد الرجوع إليها ؛ حيث يحيل الشاعر المتلقي عليها بشكل مختزل مكثف، فتمة فجوات دلالية بترك النص مهمة إكمالها للمتلقي؛ حيث يفترض أنها دلالات قارة في الذاكرة. 
د · عبيز إسحق محمد حسين لـين

الخاتمة :

و أخير فإن هذه المقاربة تظل و احدة من المقاربات الثعرية لنصوص أدبية خالصة الأدبية تغري بالبحث و الدراسة، وقد أخذت الدراسة على عاتقها سبر أغو ارها بما تمتلكه من معرفة، وفيما يلي نجمل ما توصلنا إليه من نتائج : ' يعد التقابل آلية قر ائية وتحليلية موسعة، وذللك بعد إخر اجه من مفهوم البلاغة المعيارية القديمة المرتبطة بالطباق و التضاد على مستوى المفردة إلى مفهوم الأسلوبية الحديثة، وتوسيع مجال اثتغاله في دلالته على التواجه و التفاعل، فقد أخذ أثكالاً متعددة منها الظاهر و الصريح، ومنها الخفي الذي يحتاج إلى الى إعمال عقل وتفكير، وهو ما حاولنا الاجتهاد في استكثافه من خلال تتبع مستوياته، و أنو اعه و الوقوف على دلالته وقوته التعبيرية ، فالمستويات الثناثة هي مر احل بانية لعملية الفهم المشكلة لصر ح المعنى • r. يعد التقابل اللغوي من العناصر الدالة على قوة الصناعة البيانية، فقد حضر بقوة في نصوص المديح النبوي، وأسهم بصورة و اضحة في تكثيف الدلالة الشعرية، فظهرت مجموعة من الأمثال والحكم و الأقوال السائرة في ثنايا الخطاب الثعري حقق فيها التقابل بلاغة الإقناع و التقهيم. r. أسهر التقابل الخطابي بإدر الك المقاصد الكلية المر اد إبلاغها إلى المتلقي، فهو أقرب وسيلة للفهم و إدر الك المعنى، ومرد ذلك أن الخطاطات الذهنية الأولية للمعنى تتشكل وفق أبعاد تقابلية كما أبان عن ذلك د. محمد بازي . ع. أسهر التقابل النتاصي في فتح النص على مكونات ثقافية واسعة يغتتي بها المعنى ويتقوى التأويل ويتعزز، كما ساعد على إحكام صناعة النص باعتماده على بنى تقابلية ملفوظة أو ملحوظة .

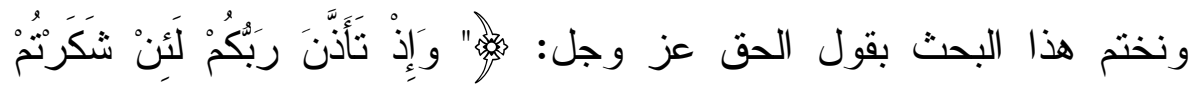

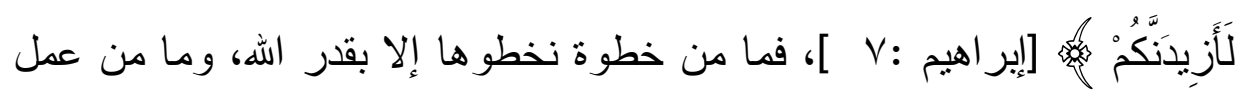


ع البناء التقابلي ينجز إلا بتيسير منه عزَّ وجل، فنشكره ونحمده على نعمه علينا، ونتبع ذلك

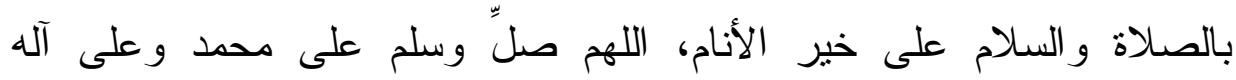
وصحبه صلاة تلإق بمقامه الكريم. والحمد الله رب العالمين ،كر، 6 
د. · عبيز إسحق محمد حسين لس

المر اجع و المصـــادر

$$
\begin{aligned}
& \text { أولاً: المصــادر } \\
& \text { هيو ان أحمد شوقي ، الجزء الأول ، دار صادر - بيروت. } \\
& \text { • لسان العرب - ابن منظور - دار صادر - بيروت. }
\end{aligned}
$$

' أدبية النص ، د. صلاح رزق ، دار التقافة العربية - الطبعة الأولى

$$
\text { . } 9 \text { ) } 9 \wedge 9-\rightarrow 1 \leq 1 \text {. }
$$

ץ. بلاغة الخطاب و علم النص ، د. صلاح فضل ، الكويت ، المجلس

الوطني للنقافة و الفنون - سلسلة عالم المعرفة ، 99 ام .

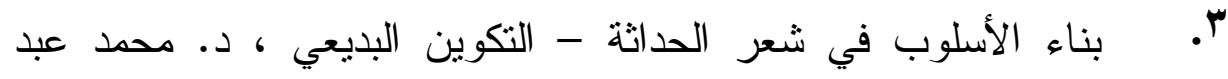

المطلب ، دار المعارف ، الطبعة الأولى بو99 ام .

؛. التقابل و التماتل في القر آن الكريم ، در اسة أسلوبية- د. فايز القرعان -

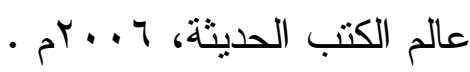

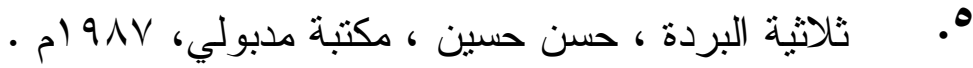

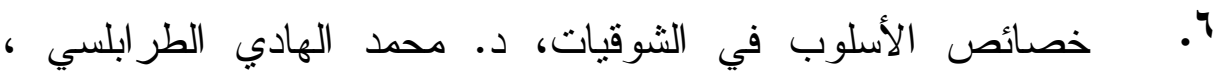

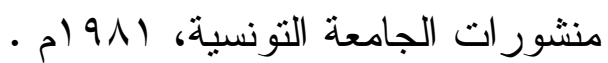

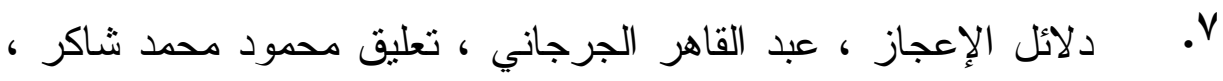

مطبعة المدني بالقاهرة ، الطبعة الثالثة.

^. السيرة النبوية كما جاءت في الأحاديث الصحيحة ( قراءة جديدة ) ،

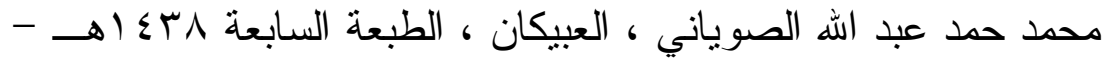

$$
\text { . }
$$

9. شرح الكواكب الدرية في مدح خير البرية المعروفة بالبردة ، الثيخ

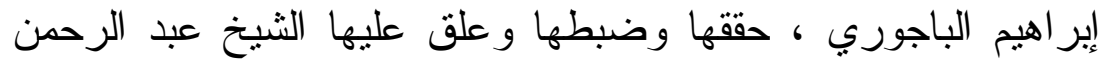
حسن محمود ، مكتبة الآداب ، ميدان الأوبرا ، القاهرة ، الطبعة الثانية 
•1. الصورة الفنية في شعر الجارم ، د. محمد حسن عبد اله ، الهيئة العامة

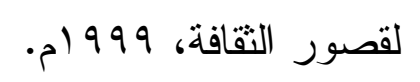

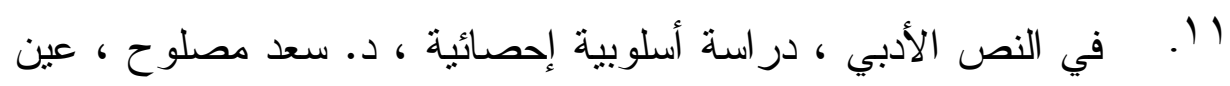

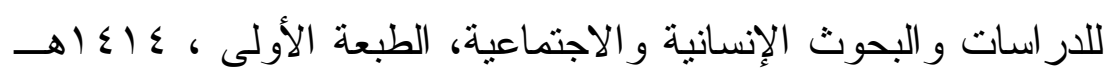

$$
\text { - م } 994
$$

r'. المتل السائر في أدب الكاتب و الثاعر ، ضياء الدين بن الأثير ، تعليق

د. أحمد الحوفي ، د. بدوي طبانة ، نهضة مصر للطباعة (د. ت ) ) .

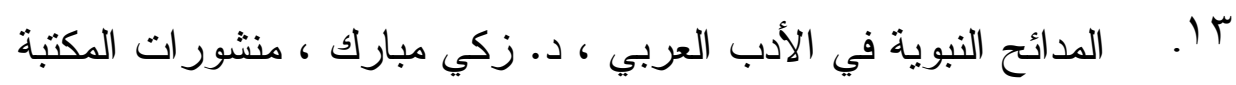

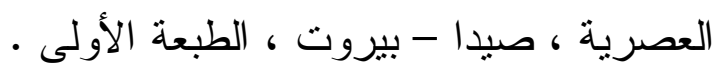

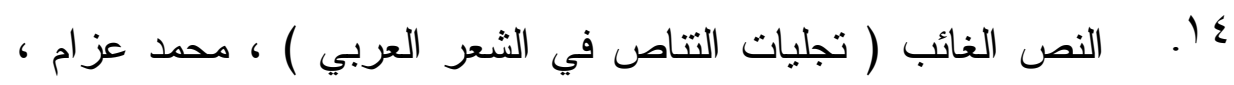

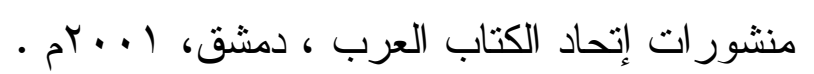

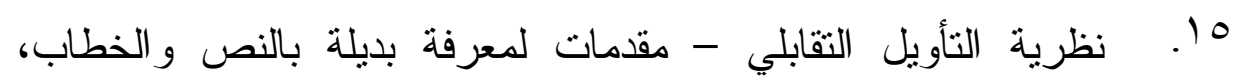

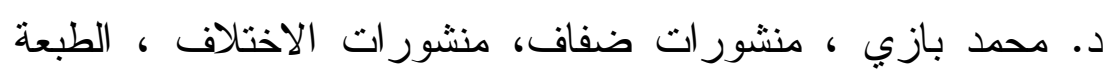

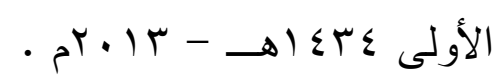

